\title{
The Globalization of Cooperative Groups
}

\author{
Manuel Valdivieso, M.D., M.S. ${ }^{1}$, Benjamin W. Corn, M.D. ${ }^{2}$, Janet E. Dancey, \\ M.D. ${ }^{3}$, D. Lawrence Wickerham, M.D. ${ }^{4}$, \\ L. Elise Horvath, M.D. ${ }^{5}$, Edith A. Perez, M.D. ${ }^{6}$, \\ Alison Urton, M.S. ${ }^{7}$, Walter M. Cronin, M.P.H. ${ }^{8}$, \\ Erica Field, M.P.H., C.C.R.P. ${ }^{9}$, \\ Evonne Lackey, B.A., C.C.R.P. ${ }^{10}$, Charles D. Blanke, M.D. ${ }^{11}$
}

${ }^{1}$ Professor of Medicine, Division of Hematology/Oncology, University of Michigan; and SWOG, Executive Officer, Quality Assurance and International Initiatives, Ann Arbor, MI; ${ }^{2}$ Benjamin W. Corn, MD, Professor and Chairman, Institute of Radiotherapy, Tel Aviv Medical Center, Tel Aviv Israel; and Adjunct Professor of Radiation Oncology, Jefferson Medical College, Philadelphia, PA;

${ }^{3}$ Director, NCIC Clinical Trials Group; Scientific Director Canadian Cancer Clinical Trials Network; Program Leader, High Impact Clinical Trials, Ontario Institute for Cancer Research; Professor of Oncology, Queen’s University, Kingston, Ontario, CAN; ${ }^{4}$ Deputy Chairman, NRG Oncology, Pittsburgh, PA; Associate Professor of Human Oncology, Pittsburgh Campus, Drexel University School of Medicine; Allegheny Cancer Center at Allegheny General Hospital, Pittsburgh, PA; ${ }^{5}$ Executive Officer, Alliance for Clinical Trials in Oncology, 
Chicago, IL; ${ }^{6}$ Deputy Director at Large, Mayo Clinic Cancer Center; Group Vice Chair, Alliance for Clinical Trials in Oncology; Hematology/Oncology and Cancer Biology Mayo Clinic, Jacksonville, FL; ${ }^{7}$ Group Administrator, NCIC Clinical Trials Group, Queen's University, Kingston, Ontario, CAN; ${ }^{8}$ Associate Director, NRG Oncology Statistics and Data Management Center (SDMC); Associate Director, Biostatistics, University of Pittsburgh Graduate School of Public Health, Pittsburgh, PA; ${ }^{9}$ Project Specialist III, RTOG, Philadelphia, PA; ${ }^{10}$ Coordinating Center Manager, SWOG Statistical Center, Seattle, WA; ${ }^{11}$ Chair, SWOG; Professor of Medicine, Division of Hematology and Medical Oncology, Oregon Health \& Science University and Knight Cancer Institute, Portland, OR

From the Alliance for Clinical Trials in Oncology, NCIC CTG, NRG Oncology, RTOG and SWOG adult NCTN research groups

Acknowledgments: Supported in part by National Institutes of Health/National Cancer Institute grants U10 CA180888, U10 CA180819, UG1 CA189974, U10 CA12027, U10 CA37377, U10 CA69651, U10 CA69974, U10 CA21661, U10 CA37422, U10 CA180821, U10 CA1844; Canadian Cancer Society Research Institute (CCSRI) grant 021039; and the Bill and Melinda Gates Foundation. The authors wish to thank Ms. Sherry Breaux, M.P.H., Publications Operations Manager, Alliance for Clinical Trials in Oncology; Ms. Veronica Garcia, B.S., 
SWOG Latin American Specialist - QA and Membership; and Ms. Patricia Arlauskas, B.A., SWOG Publications Coordinator, for their assistance in the preparation of this manuscript.

Corresponding Author: $\quad$ Manuel Valdivieso, M.D., M.S., C.P.E.

University of Michigan Comprehensive Cancer

Center

Division of Hematology/Oncology

C335 Med Inn Bldg.

1500 E Medical Dr., SPC 5848

Ann Arbor, Michigan 48109

Tel: 734-998-8221; Fax: 734-615- 2109

e-mail: manuelva@med.umich.edu

\begin{abstract}
The National Cancer Institute-supported adult cooperative oncology research groups (now officially Network groups) have a long-standing history of participating in international collaborations throughout the world. Most
\end{abstract}


frequently, the U.S. based cooperative groups work reciprocally with the Canadian national adult cancer clinical trial group, NCIC CTG (previously the National Cancer Institute of Canada Clinical Trials Group). Thus, Canada is the largest contributor to cooperative groups based in the U.S., and vice versa.

Although international collaborations have many benefits, they are most frequently utilized to enhance patient accrual to large phase III trials originating in the U.S. or Canada. Within the cooperative group setting, adequate attention has not been given to the study of cancers that are unique to countries outside the U.S. and Canada, such as those frequently associated with infections in Latin America, Asia and Africa. Global collaborations are limited by a number of barriers, some of which are unique to the countries involved, while others are related to financial support and to U.S. policies that restrict drug distribution outside the U.S. This manuscript serves to detail the cooperative group experience in international research and describe how international collaboration in cancer clinical trials is a promising and important area that requires greater consideration in the future.

\section{INTRODUCTION}

Cancer is one of the most common worldwide causes of morbidity and mortality. It is estimated that in 2012, there were 14.1 million adults diagnosed with cancer and 8.2 million deaths attributable to this disease. It is also estimated that the number of cancer cases will increase from 14.1 million in 2012 to 22 million in 
the next two decades. ${ }^{1}$ The most common cancers in adults are breast, prostate, lung and gastric cancers. From the standpoint of mortality, lung and gastric cancers are, respectively, the first and second most common causes of cancer death in the world. $^{2}$ Globally, more than $60 \%$ of the total number of new cases diagnosed annually occur in Africa, Asia and Central and South America. These regions account for $70 \%$ of the world's cancer deaths. ${ }^{1}$ This is particularly important to the U.S. and other developed countries because of immigration from these regions and its subsequent effect on the makeup of their populations. For example, Hispanics are the largest minority in the U.S., comprising $16.3 \%$ of the total population in 2010 , and having grown by $43 \%$ since 2000 . At this rate, it is estimated that by 2050, one of every four Americans will be Hispanic. ${ }^{3}$ It is not fully known what the impacts of immigration will be on cancer epidemiology in the US, but it behooves the U.S. medical community to be prepared for change.

Cancer-related risk factors also vary geographically. Tobacco use is the most important cancer risk factor responsible for $20 \%$ of global cancer deaths and approximately $70 \%$ of global lung cancer deaths. Infections represent a risk factor that starkly differs among regions, and they are related to 8\% of cancers in developed nations and up to $23 \%$ in countries under development. Cancer causing viral infections such as $\mathrm{HBV} / \mathrm{HCV}$ and $\mathrm{HPV}$ are responsible for up to $20 \%$ of cancer deaths in low- and middle-income countries. ${ }^{2}$ Cervical cancer, a 
consequence of HPV along with lack of access to appropriate screening, is a leading cause of death in low-income countries.

With the increasing improvements in our understanding of the molecular biology of cancer and the subsequent development of improved methods of cancer prevention, detection and therapy, there is increasing interest in applying these methods to improve cancer control throughout the world. In the U.S., these efforts are led by the National Cancer Institute (NCI) through its Center of Global Health and other institutes at the National Institute of Health (NIH). Trimble et al. has described these efforts and those of other centers around the world, efforts that have led to improved standardization of cancer staging, increased awareness of the importance of securing patient's informed consent, better understanding of developing, applying, monitoring and publishing cancer clinical trials, as well as the limitations of applying these efforts due to economics, politics, regulatory, tissue procurement and distribution, drug distribution and other issues. ${ }^{4}$ Additionally, and in response to the increasing interest of U.S. Cooperative Groups in international trials participation, the NCI-CTEP is working collaboratively with both the Food and Drug Administration (FDA) and with the Office for Human Research Protections (OHRP) on the clarification of regulatory and logistical aspects regarding the entire clinical trials process, including design, implementation, monitoring, analysis and publication of trial results that include 
NCI-sponsored Cancer Cooperative Groups

(http://ctep.cancer.gov/branches/ctmb/clinicalTrials/docs/nci_clin_intl_guidelines. pdf).

As an extension of the interest of the US Government to improve the infrastructure of Europe after the Second World War, resources were provided for the establishment of the European Organization for Research and Treatment of Cancer (EORTC) in 1962. Subsequently, funding assistance was provided to the former National Cancer Institute of Canada Clinical Trials Group (now known as “NCIC Clinical Trials Group”) (NCIC CTG)) in 1997. All involved countries have significantly now contributed to the sustainability of these efforts.

The NCI-sponsored U.S., Network groups have extended their trial network to include many countries around the world. These efforts have been primarily focused on Canada, where a strong clinical research partnership has been developed with the NCI CTG. Other efforts principally involve Europe and Australia and, to a lesser extent, Asia and Latin America. This article provides an overview of international collaborations coordinated by the NCI-sponsored adult cooperative oncology research groups.

\section{SEEKING INFORMATION ON GLOBALIZATION FROM ADULT} COOPERATIVE GROUPS 
The leadership of the NCTN was invited to participate in this review and asked to provide their experience on international collaborations, including information on countries, sites, investigators, and clinical trials and associated publications.

This article includes summary tables of the groups' involvement in international collaborations, although data on patient accrual and publications are available for only those groups providing this information. Overall activity is summarized in Table 1.

\section{NCIC CTG EXPERIENCE}

Overview and the NCIC CTG Perspective

Established in 1980, the NCIC CTG has 273 phase III ongoing or completed studies, as well as 197 Investigational New Drug trials, enrolling a total of over 75,000 patients. NCIC CTG has collaborated with sites in 41 countries, across 54 trials, with 26189 patients accrued. It is important to note the significance of the partnership with US cooperative groups and sites that contributed 18624 of the 26189 patients accrued through these collaborations. A summary of international participation is provided in Table $2 .^{5-49}$ Globalization of clinical trials is critical in moving the research agenda forward. Benefits of globalization include: a) facilitation of regulatory filings in multiple regions using a Common Technical Document (CTD); b) increased applicability of results to multiple regions; c) increased speed in time to activate, accrue, analyze and, ultimately, answer the 
trial question; and, d) access to emerging information and new treatment options for patients in need. Given the benefits, continued effort is essential to overcome the economic, political, regulatory, contractual, and drug related challenges in the global clinical trials environment.

\section{History of Collaboration}

NCIC CTG has collaborated with international sites in the US and Europe since the early 1980’s. This expanded to cooperative group collaborations in the early 1990’s. Subsequently, NCIC CTG successfully applied for NCI/CTEP funding in 1997. This grant, renewed in 2003 and 2008, serves two main purposes: i) to develop, conduct and provide leadership of trials that engage the U.S. investigative community in a manner that meets U.S. scientific interests, regulatory standards and represents value from the perspective of expenditure of U.S. federal dollars; and, ii) to conduct in Canada trials led by U.S.-based groups, including the provision of operational and regulatory oversight that complies with U.S. and Canadian expectations and requirements. Important secondary purposes include contributions to scientific, operational, data management and regulatory advancements. More recently, the NCIC CTG became the Canadian Collaborating Partner of the National Clinical Trials Network (NCTN) with the aim to continue to enhance these relationships through the contributions of a highly organized Canadian network. 
Models of Collaboration

NCIC CTG conducts these trials in several ways referred to as the Intergroup or International models. In the Intergroup Model, the lead cooperative group would organize the trial and communication strategy, oversee all central data management and cleaning, analyze the trial, and prepare the primary publication. The lead cooperative group would also act as sponsor with associated responsibilities in their own region. From there, other academic cooperative groups could join and an Intergroup Agreement with roles and responsibilities assigned would be executed. The other academic cooperative groups would act as local sponsor in their region, be responsible for site activation and data collection, as any issues that may arise. The intergroup model is typically found to be more cost effective and generally uses a risk-based approach (i.e., regulatory risk differentiation to systemically treat entities differently based on the regulator's assessment of the risks of the entity's non-compliance) to oversight and quality assurance processes. An example of the Intergroup Model is the MA32 study, A Phase III Randomized Trial of Metformin versus Placebo on Recurrence and Survival in Early Stage Breast Cancer, This trial was developed by NCIC CTG, activated 2010 JUN 25, and closed to accrual 2013 JAN 22. Including Canada, international centers and groups from Switzerland, the UK, and the US participated in the study. A total of 3649 patients were accrued with 33\% coming 
from Canada and 67\% from the rest of the world with the majority through the US CTSU mechanism. The international partnerships facilitated timely activation and accrual.

In the International Model, the lead cooperative group would similarly enter into a contract with a pharmaceutical partner and from there lead organization/communication on the trial, oversee all central data management and cleaning, and ultimately analyze and publish/present the trial. The lead cooperative group would also act as sponsor with associated responsibilities in their own region. From there, company would act as local sponsor or this may be delegated to a Contract Research Organization (CRO). The international model is typically most resource and cost intensive and often used when new registration of an agent is planned.

A successful example of the International Model was the BR21 study, A Randomized Placebo Controlled Study of OSI-774 (Tarceva) in Patients with Incurable Stage IIIB/IV Non-Small Cell Lung Cancer Who Have Failed Standard Therapy for Advanced or Metastatic Disease. ${ }^{5}$ This trial was developed by NCIC CTG, was activated on 2001 AUG 14, the first patient was randomized 2001 NOV 01, and the trial completed accrual on 2003 JAN 31, just over 2 years after the trial was activated. Including Canada, 17 countries and 97 centers participated 
around the world. A total of 731 patients were randomized with $25 \%$ of patients coming from Canada and 75\% from the rest of the world. Benefits of this international effort included speed in time to activate, accrue, and ultimately answer the study question. This also facilitated filings as well as increased applicability of study results in multiple regions. This study would not have been possible without the partnership around the world.

\section{NSABP EXPERIENCE}

The list of international sites that have participated in current and past NSABP studies covers the period from 1971 to the present. It includes 41 different institutions or organizations. Some of the organizations are actually themselves research groups, such as the Irish Clinical Oncology research Group (ICORG), which participated as full members of the NSABP. Overall, these sites have entered more than 14,000 patients into NSABP's NCI-funded CTEP trials or about $13 \%$ of the total accrual. This number does not include the NSABP's primary prevention trials supported through the NCI's Division of Cancer Prevention. Historically, all NSABP trials have been made available to its international participants, except in cases where the supporting pharmaceutical company had distribution or formulation issues that precluded activating a trial in a given country. More recently, NCI drug distribution and regulatory issues have hampered international participation. Individual institutions could self-select not to open a specific trial at their discretion. 
Canadian participation has been particularly key to the success of NSABP studies. The Canadian sites have been major participants in many NSABP trials, and their investigators have been active in the scientific and administrative committees of the NSABP, including the Board of Directors. Dr. Alexander Patterson, from the Tom Baker Cancer Center in Calgary, is the protocol chair for NSABP Protocol B-34, "Clodronate With or Without Chemotherapy and/or Hormonal Therapy in Treating Women With Stage I or Stage II Breast Cancer," which was recently published in Lancet Oncology. ${ }^{50}$ Dr. Richard Margolese, from the Jewish General Hospital in Montreal, is the protocol chair for NSABP B-35, “Anastrozole or Tamoxifen in Treating Postmenopausal Women With Ductal Carcinoma in Situ Who Are Undergoing Lumpectomy and Radiation Therapy.” The B-35 study has completed accrual with 3000 patients but has not yet reached final data collection date for primary outcome measures. A summary of international participation in NSABP trials is provided in Table $3 .^{50-103}$

\section{RTOG EXPERIENCE}

The RTOG elected to globalize its activity in 2004. The first international site to be accepted was Tel Aviv Medical Center. Within a year, hospitals from South 
Korea and Australia were also invited to join as affiliates. Currently, 29 centers participate from 14 countries and 5 continents.

The motivation for expanding towards an international catchment was both altruistic and pragmatic in nature. From an altruistic standpoint, enrollment of patients on RTOG protocols would result in improving the standard of care for patients enrolled onto clinical trials, with an anticipated concomitant "spillover effect” for those receiving standard therapy in a facility whose rigor of quality assurance was very likely upgraded in order to achieve endorsement during RTOG audits. On a pragmatic level, RTOG leadership understood that international expansion would accelerate trial execution by virtue of rapid enrollment and would also provide access to genetically diverse populations not necessarily residing in North America. Furthermore, it was hoped that new standards emerging from RTOG protocols would more rapidly penetrate clinical practice if a broad set of international centers were to participate.

An illustrative case of the success of the RTOG Intercontinental Committee is derived from RTOG 0525. In that trial, the largest study to date conducted for glioblastoma multiforme (GBM), a very rare but particularly malignant brain tumor, the leading accruing site was an Intercontinental group member (Tel Aviv Medical Center). Some historical background is needed to understand what lead to this exemplary participation. 
In Israel, where national health legislation has been available in some form since the founding of the state in 1948, a committee meets annually to revise the "basket" of goods and services that are provided to all citizens. ${ }^{105}$ Unfortunately, these entitlements often lag behind the establishment of new standards of care. In 2005, a study appeared in the New England Journal of Medicine, which established a new treatment paradigm for GBM. Stupp and colleagues demonstrated that instead of treating with radiotherapy alone, the combination of radiotherapy and Temozolomide nearly doubled survival rates. ${ }^{106}$ The drug, manufactured by Schering Plough, was priced at 40,000 shekels (approximately $\$ 10,000$ USD in 2005) per month and was to be taken for a full year. Temozolomide, however, was not added to the aforementioned "basket" until approximately two years after the publication of the GBM trial. Israeli citizens diagnosed with GBM who could not afford to pay $\$ 120,000$ annually for the drug had no recourse. Because many of the Israeli patients were savvy medical consumers, a creative solution emerged. Israelis obtained access to a clinical trial sponsored by the National Cancer Institute (i.e., RTOG 0525), which randomized patients with GBM to irradiation plus standard dose temozolomide versus irradiation plus dose-intensified temozolomide. In both the standard and experimental arms of the study, patients received the drug gratis from the NCI. Hence, Israel became the leading site accruing patients to this study, outpacing even highly regarded academic facilities in the U.S. 
An evolving story of success is RTOG 1119 for brain metastases in the context of Her-2 positive breast cancer. This randomized phase II trial was initiated by an Intercontinental Committee member from Seoul National University Bundang Hospital. In contrast to the case study of RTOG 0525, which was partly driven by the lack of availability of the lead drug (Temozolomide) at one of the centers, RTOG 1119 has thrived because of the ability of four centers comprising the Korean Radiation Oncology Group (KROG) to obtain the experimental agent (i.e., Lapatanib). Trial 1119, which offers many opportunities for comparative genetic studies among participating populations, emerged from fruitful discussions at the Intercontinental Committee of RTOG with subsequent input from the Brain Tumor Committee and the Breast Cancer Committee, respectively.

Indeed, medical centers from outside the boundaries of North America convene at the semi-annual meeting of the RTOG in the context of the "Intercontinental Committee” which has a Chair and a Vice Chair, who by definition represent separate countries of origin. At the most recent meeting of the Intercontinental Committee, an informal survey was conducted to identify common difficulties experienced while participating in RTOG trials (at that time under the auspices of NRG Oncology). Minor concerns included time zone difference vis-à-vis RTOG headquarters in Philadelphia, which relegated most communication to email 
correspondence without a "personal touch.” Of greater concern was pressure from international centers to retain tissue locally at the same time most RTOG protocols are mandating specimen submission to the group's genetic data bank, expense of translating and validating supplementary tools (especially quality-oflife related surveys) at a time when ancillary studies (e.g., neurocognitive testing) are being sought. In addition, a consensus - if not a grievance - existed in relation to the mandatory $\$ 10,000$ entrance fee for RTOG site membership used at that time to cover administrative expenses, including auditing activities. Overall, however, the participating intercontinental centers expressed pride to be a part of the RTOG, which is exemplified by the continuous stream of applicants seeking to join the group. The membership fee for international site participation within the context of NRG Oncology has been discontinued.

RTOG international participation is summarized in Table $4 .{ }^{107-126}$

\section{SWOG EXPERIENCE}

Over the past four decades, SWOG has collaborated with 93 centers in 14 countries, including 66 sites in Canada. A total of 8925 patients were accrued to 48 studies, including solid tumors and hematologic malignancies. Leading accruing sites were Canada (4522), Puerto Rico (1463), Mexico (678) and Spain (499). These studies generated the publication of 35 primary results papers. 
Included were the evaluation of imatinib mesylate in patients with gastrointestinal stromal tumors ${ }^{127}$; the evaluation of intermittent vs. continues androgen deprivation in patients with prostate cancer ${ }^{128}$; effect of selenium and vitamin $\mathrm{E}$ on risk of prostate cancer ${ }^{129,130}$; and prospective randomized clinical trial of three antibiotic regimes for the treatment of Helicobacter pylori infection in Latin America. ${ }^{131,132}$ International collaboration activity is summarized in Table 5. ${ }^{127-161}$

A focused effort was made recently to study disease processes that were far more common in other countries than in the U.S., resulting in a prospective randomized clinical trial of three antibiotics regimen for the treatment of infection by Helicobacter pylori in seven sites, six countries, of Latin America. ${ }^{131,132}$ More than 1463 patients were accrued by the study sites. The investigators were highly capable and cooperative, and study requirements were met or exceeded. The study was principally supported by a grant from the Bill and Melinda Gates Foundation. Many lessons were learned with the implementation and conduct of this trial, including the different requirements and timetables of each country towards providing Institutional Review Board (IRB) approval. Several sites would not permit specimens to be collected and stored long term for future, unspecified use. The procurement and delivery of the urea breath tests (UBT) machine from Europe to each site, overcoming each country's customs authority, 
and the reliable functioning of such machines offered challenges that needed great attention by the central coordinating center in the U.S. All study forms needed to be translated into Spanish; appropriate training of technical personnel was done on site; multiple queries were issued when data entry questions developed; weekly meetings of all investigators with the central coordinating center were conducted via telephone conferencing; and the central coordinating team conducted audit visits to each site twice a year.

Over the course of this trial, SWOG planned for regulatory delays, customs, drug distribution and specimen shipment. Chile experienced a devastating earthquake at the height of accrual. Nicaragua, Mexico and Costa Rica suffered the worst rainstorms in recent years knocking out power, washing away roads and creating food shortages. Honduras experienced a coup, and Colombia was in the middle of political elections that sporadically impacted trial operations. Despite the obstacles encountered along the way, the Helicobacter pylori trial was a success. ${ }^{131,132}$ Even with regulatory and customs delays, it reached accrual goals through the efforts of staff committed to the success of the trial. We encountered no significant problems with internet connectivity. Sites administered a total of 4,612 urea breath tests, and adverse events across all treatments were minimal. Most important of all, Latin American medical professionals can now confidently recommend the 14-day antibiotic regimen as the best regimen to eradicate 
Helicobacter pylori in their patient populations, and we know that such trials can be successfully conducted in Latin America.

\section{THE ALLIANCE EXPERIENCE:}

The Alliance for Clinical Trials in Oncology was created as a merger between 3

“legacy” groups: ACOSOG, CALGB, and NCCTG. The 3 legacy groups all had a strong history of international sites and collaborations. Between the groups, there have been numerous collaborators, involving 2 countries in Australia, 10 in Asia, 2 in North America, 3 in South America and 21 in Europe, with a total international accrual of 10,105 since 1966. The summary of these experiences is detailed in Table $6 .^{(162-212)}$

There are 2 trials that highlight work that began in the legacy groups and is being completed by the Alliance. The first is a trial, N063D, Adjuvant Lapatinib and/or Trastuzumab Treatment Optimization (ALTTO) Trial. ALTTO was a codeveloped trial between the legacy NCCTG and the Breast International Group (BIG), with funding from the NCI and Glaxo Smith Kline. The trial was an excellent example of academic collaboration between the NCI and the international oncology institutions, with pharmaceutical partnership. All study forms were developed with input from all partners. The trial structure involved 2 co-PIs (one from each academic group), an executive committee that included a 
statistician from each group and several global collaborators, and a steering committee of approximately 50 members. Added to almost daily global interactions via internet, there were monthly operations meetings during the 4 years of accrual, then less frequently afterwards. The study helped identify barriers to trial activation in different countries, identified discordance problems with HER2 as a biomarker - which led to educational initiatives to improve validity of testing. All of this resulted in improved access to anti-HER2 therapies for women in more than 40 countries. The biospecimens collected will be used to conduct correlative studies for treatment efficacy and toxicity overall, and also to address potential differences based on country.

The Alliance also has worked on the completion of accrual and the analysis of data for CALGB 10603, “A Phase III randomized double blind study of induction (daunorubicin/ cytarabine) and consolidation (high-dose cytarabine) chemotherapy and midostaurin or placebo in newly diagnosed patients $<60$ years of age with FLT3 mutated acute myeloid leukemia”, also known as the RATIFY trial. This was a complex, biomarker driven trial, involving collaborators from multiple countries or organizations (EORTC ; GIMEMA; German Austrian AML study group; OSHO; SAL; PETHEMA; CETLAM; Brazil; Hungary; Australia; France; Czech Republic; UK; Slovakia; Israel; Argentina; Mexico), with Richard 
Stone, M.D., as the U.S. study chair. Again, there was presence of an industry collaborator in Novartis. The study accrued rapidly, with over 2400 AML patients pre-screened and over 700 patients enrolled in 3.5 years. Dissemination of biomarker results was very rapid, with US time of 26 hours, thus facilitating site participation. Operationally, while it was complex toorganize, the trial ran well and was very successful, as evidenced by the rapid enrollment. ${ }^{202,203}$ Linda Bressler, Pharm. D., should be credited for her diligence and dedication to the trial, and her time invested in operations.

There are several recent collaborations described below that have identified hurdles which exist for international collaborations as a whole, and the barriers found are representative of international cooperative group studies of the present and future:

- $\quad$ Two collaborations are being investigated with the EORTC, for testicular cancer and for salivary cancer

- $\quad$ Collaboration with Switzerland (SAKK) and with Hospital de Gastroenterología Dr. Carlos Bonorino Udaondo, Buenos Aires, Argentina, has been finalized for study N1048, “A Phase II/III Trial of Neoadjuvant FOLFOX with Selective Use of Combined Modality Chemoradiation versus Preoperative Combined Modality Chemoradiation for Locally Advanced Rectal Cancer Patients Undergoing Low Anterior Resection with Total Mesorectal Excision.” 
- $\quad$ Collaboration is ongoing with several Canadian member sites, Princess Margaret Cancer Center, Toronto, ON, Canada; London Regional Cancer Center, London, ON, Canada; Allan Blair Cancer Centre, Regina, SK, Canada on multiple trials.

- All of these studies require utmost attention to detail with regard to initial feasibility, then the appropriate delineation of responsibilities for the Alliance and the counterpart abroad, including the following issues:

o cientific agreement on the study and its design between the U.S., non-U.S. group, and the NCI

o linguistictranslation of protocol, study forms and consent form

o development of group-specific appendix

o handling of protocol amendments

o obtaining and shipping biologic samples under biobanking agreement when needed

o costs of shipping specimens and banking; maintaining specimen conditions with international shipment

o coordinating techniques between central labs in separate nations to ensure uniformity

o drug supply, distribution and import/export arrangements 
o studies of quality of life with instruments that have been approved among collaborating partners and language barriers therein

o developing an agreement/ that is approved by both parties and the NCI

o harmonizing registration/randomization in 1 system

o meeting clinical NCI reporting requirements with a non-U.S. database

o rostering of international members

o coordinating separate IT systems

o simultaneous collaboration with pharmaceutical companies

o time zone differences especially in answering urgent queries or dealing with safety

o capacity of a study site to meet accrual expectations for membership

o study site burden in utilizing a novel electronic case record form

- International collaborations further include daunting regulatory considerations, as the regulations need to be met for both sides. Some of the major regulatory hurdles that need to be resolved are the following: 
o differing guidelines and regulations for safety reporting and pharmacovigilence with resultant needs for double reporting for sites and burdens on the cooperative group

o meeting drug labeling requirements and other regulatory considerations surrounding drug

o meeting and harmonizing the data protection directives and privacy laws which differ between countries

o differences in regulations for record retention and their subsequent harmonization

o coordination of audit techniques and their approvals;

o periodic audit of member sites with resultant financial cost and resource loss for audits outside the US

o obtaining human subject protection and state department clearances

o harmonizing of regulations for IRB/ethics committees

o paperwork burden and additional training for sites and investigators

o study specific certifications such as radiation safety and therapy certifications. 


\section{DISCUSSION}

NCTN groups have a long-standing history of collaboration with international cancer units around the world. The most important incentive for these collaborations appears to be the desire to improve patient accrual of large phase III trials in the U.S. and Canada. Many international sites likewise benefit by the experience of working with well-organized and experienced clinical trials organizations that facilitate their access to newer and often expensive cancer treatments provided by the treatment protocols. These interactions are usually viewed very positively by all of the parties involved.

Cooperative groups in the U.S. have reached out to many countries around the

world, mainly Canada, Western Europe, Australia and Latin America. Canada, by far, is the most active participant accruing patients onto U.S.-based clinical trials. The same reciprocal phenomenon is observed in Canada, since the U.S. is responsible for the largest number of patients accrued onto NCIC CTG-based protocols. Hence, a close clinical trials collaboration has thus evolved between the two countries.

NCIC CTG competes for funding from the U.S. government, as do the other cooperative groups, so the benefit sought by the funding agency in terms of larger accrual to clinical trials is achieved. These and other international collaborations 
have resulted in important contributions to the cancer literature. Similar success has been achieved in Europe with its own European Organization for Research and Treatment of Cancer (EORTC) based on strong collaboration among European nations although this collaboration has occasionally included the U.S. and Canada.

It is important to realize that the support provided by the U.S. government to Europe, including the formation of the EORTC, was a success. Similarly, the support of the U.S. to Canada for the NCIC CTG to expand collaborations with U.S. cooperative groups has successfully enriched trial opportunities for patients and improved trial recruitment in both countries. Unfortunately, other parts of the world with important cancer issues, such as infection-related cancers, lag in support by their own countries and the U.S. government. Included are Africa, parts of Asia and Latin America - the latter, our neighbors to the south, with over 700 million inhabitants. The continuing immigration of large numbers of Hispanics to this country and the rapid growth of Hispanics in the U.S. make the need for cancer research efforts in Latin America even more critical.

The international collaboration of U.S.-funded cooperative groups has until now, not focused on the study of genomics of common cancers in distant parts of the world.Such study could produce meaningful results for cancer control and 
treatment in those areas. Also, there has been a notable lack of clinical trials designed to prevent, treat and study infection-related cancers. In general and genomically cancers of the stomach, cervix and liver are due to Helicobacter pylori, $\mathrm{HPV}$ and $\mathrm{HBV} / \mathrm{HCV}$, respectivelyand require attention of global collaborative partnerships. They are common in countries under development and often represent the most common causes of cancer incidence and mortality in some areas of Latin America, Asia and Africa. In this regard, the efforts of SWOG in developing treatment protocols for $H$. pylori infection in Latin America have been highly successful.$^{131,132}$ The NCI has also started a pilot clinical genomic protocol of 1000 breast cancer patients in several countries of Latin America (http://www.cancer.gov/aboutnci/organization/global-health/researchprograms-initiatives/us-la-crn ) that is being conducted by the Latin America Research Network (US-LA CRN). These initial steps are important and, hopefully, will be expanded in the future.

The conduct of international cancer clinical trials still faces a number of challenges. Aside from the need to translate clinical trial protocols into another language(s), there is the necessity for adequate contracting to assure that responsibilities are carefully elucidated, and the need to attend to regulatory constraints unique to the country and often difficult to resolve, particularly with respect to biospecimen collection and release. Drug supply and distribution to 
international sites is frequently difficult and not facilitated by current U.S. policies. All of these factors may adversely affect the conduct of the clinical trial abroad. In addition, close monitoring of such trials must be performed to assure patient safety. Last but not least, appropriate funding of international trials must be scrutinized as the costs of conducting trials abroad are, at times, more expensive than in the US. In spite of these deterrents, international collaborations are of benefit to all involved and, most importantly, to participating, current, and future cancer patients.

\section{REFERENCES}

1. World Health Organization, International Agency for Research on Cancer, Globocan 2012: Estimated Cancer Incidence, Mortality and Prevalence Worldwide in 2012. Retrieved from http://globocan.iarc.fr/Default.aspx

2. de Martel C, Ferlay J, Franceschi S, et al. Global burden of cancers attributable to infections in 2008: a review and synthetic analysis. Lancet Oncol. 2012; 13:607-615.

3. U.S. Department of Commerce, United States Census Bureau, 2010 Census. Retrieved from http://www.census.gov/2010census/

4. Trimble EL, Abrams JS, Meyer RM, Calvo F, Cazap E, Deye J et al. Improving cancer outcomes through international collaboration in academic cancer treatment trials. J Clin Oncol 2009; 27:5109-5114. 
5. Shepherd F, Pereira JR, Ciuleanu T et al. Erlotinib in previously treated non-small-cell lung cancer. N Engl J Med 2005; 353(2):123-132.

6. Goss GD, Arnold A, Shepherd FA, Dediu M, Ciuleanu T, Fenton D et al. Randomized, double-blind trial of carboplatin and paclitaxel with either daily oral cediranib or placebo in advanced non-small-cell lung cancer: NCIC Clinical Trials Group BR24 study. J Clin Oncol 2910; 28(1):49-55.

7. Moore MJ, Goldstein D, Hamm J, Figer A, Hecht JR, Gallinger S et al. Erlotinib plus gemcitabine compared with gemcitabine alone in patients with advanced pancreatic cancer: a phase III trial of the National Cancer Institute of Canada Clinical Trials Group. J Clin Oncol. 2007; 25(15):1960-1966.

8. Laurie SA, Solomon BJ, Seymour L, Ellis PM, Goss GD, Shepherd FA et al. Randomised, double-blind trial of carboplatin and paclitaxel with daily oral cediranib or placebo in patients with advanced non-small cell lung cancer: NCIC Clinical Trials Group study BR29. Eur J Cancer. 2014; 50(4):706-712.

9. Jonker DJ, O'Callaghan CJ, Karapetis CS, Zalcberg JR, Tu D, Au H et al. Cetuximab for the treatment of colorectal cancer. N Eng J Med 2007; 357(20):2040-2048.

10. Siu LL, Shapiro JD, Jonker DJ, Karapetis CS, Zalcberg JR, Simes J et al. Phase III randomized, placebo-controlled study of cetuximab plus brivanib 
alaninate versus cetuximab plus placebo in patients with metastatic, chemotherapy-refractory, wild-type K-RAS colorectal carcinoma: the NCIC Clinical Trials Group and AGITG CO.20 Trial. J Clin Oncol. 2013; 31(19):2477-2484.

11. The ASTEC/EN.5 writing committee on behalf of the ASTEC/EN.5 Study Group; Blake P, Swart AM, Orton J, Kitchener H, Whelan T, Lukka H et al. Adjuvant external beam radiotherapy in the treatment of endometrial cancer (MRC ASTEC and NCIC CTG EN.5 randomised trials): pooled trial results, systematic review, and meta-analysis. Lancet. 2009; 373(9658):137-146.

12. Connors JM, Klimo P, Adams G, Burns BF, Cooper I, Meyer RM et al. Treatment of advanced Hodgkin's disease with chemotherapy comparison of MOPP/ABV hybrid regimen with alternating courses of MOPP and ABVD: a report from the National Cancer Institute of Canada Clinical Trials Group. J Clin Oncol 1997; 15(4):1638-1645.

13. Eisenhauer EA, Evans WK, Raghavan D, Desmeules MJ, Murray NR, Stuart-Harris R et al. Phase II study of mitoxantrone in patients with mesothelioma: a National Cancer Institute of Canada Clinical Trials Group study. Cancer Treat Rep 1986; 70(8):1029-1030.

14. Reyno L, Seymour L, Tu D, Dent S, Gelmon K, Walley B et al. Phase III study of N,N-Diethyl-2-[4-(Phenylmethyl) Phenoxy] Ethanamine (BMS- 
217380-01) combined with doxorubicin versus doxorubicin alone in metastatic/recurrent breast cancer: National Cancer Institute of Canada Clinical Trials Group Study MA.19. J Clin Oncol 2004; 22(2):269-276.

15. Chow E, van der Linden YM, Roos D, Hartsell W, Hoskin P, Wu JS et al. Single versus multiple fractions of repeat radiation for painful bone metastases: a randomised, controlled, non-inferiority trial. Lancet Oncol. 2014; 15(2):164-171.

16. Leighl N, Paz-Ares L, Douillard JY, Peschel C, Arnold A, Depierre A et al. Randomized phase III study of matrix metalloproteinase inhibitor BMS-275291 in combination with paclitaxel and carboplatin in advanced non-small-cell lung cancer: National Cancer Institute of Canada-Clinical Trials Group Study BR.18. J Clin Oncol. 2005; 23(12):2831-2839.

17. Douillard J, Peschel C, Shepherd F, Paz-Ares L, Arnold A, Davis M et al. Randomized phase II feasibility study of combining the matrix metalloproteinase inhibitor BMS-275291 with paclitaxel plus carboplatin in advanced non-small cell lung cancer. Lung Cancer 2004:46(3):361-368.

18. Hirte H, Vergote IB, Jeffrey JR, Grimshaw RN, Coppieters S, Schwartz B et al. A phase III randomized trial of BAY 12-9566 (tanomastat) as maintainence therapy in patients with advanced ovarian cancer responsive to primary surgery and paclitaxel/platinum containing chemotherapy: a 
National Cancer Institute of Canada Clinical Trials Group study. Gynecol Oncol 2006; 102(2):300-308.

19. Shepherd FA, Giaccone G, Seymour L, Debruyne C, Bezjak A, Hirsh V et al. Prospective, randomized, double-blind, placebo-controlled trial of marimastat after response to first-line chemotherapy in patients with small-cell lung cancer: a trial of the National Cancer Institute of CanadaClinical Trials Group and the European Organization for Research and Treatment of Cancer. J Clin Oncol. 2002;20(22):4434-4439.

20. Hoskins P, Eisenhauer E, Vergote I, Dubuc-Lissoir J, Fisher B, Grimshaw R. Phase II feasibility study of sequential couplets of cisplatin/topotecan followed by paclitaxel/cisplatin as primary treatment for advanced epithelial ovarian cancer: A National Cancer Institute of Canada Clinical Trials Group study. J Clin Oncol 2000; 18(24):4038-4044.

21. Goss PE, Ingle JN, Martino S, Robert NJ, Muss HB, Piccart MJ et al. Randomized trial of letrozole following tamoxifen as extended adjuvant therapy in receptor-positive breast cancer: updated findings from NCIC CTG MA.17. J Natl Cancer Inst 2005; 97(17):1262-1271.

22. Goss PE, Ingle JN, Martino S, Robert NJ, Muss HB, Piccart MJ et al. A randomized trial of letrozole in postmenopausal women after five years of tamoxifen therapy for early-stage breast cancer. N Engl J Med 2003; 349(19):1793-1802. 
23. Hoskins P, Vergote I, Cervantes A, Tu D, Stuart G, Zola P et al. Advanced ovarian cancer: Phase III randomized study of sequential cisplatintopotecan and carboplatin-paclitaxel vs carboplatin-paclitaxel. J Natl Cancer Inst 2010; 102(20):1547-1556.

24. Eisenhauer EA, Ten Bokkel-Huinink WW, Swenerton KD, Gianni L, Myles J, van der Burg MEL et al. European-Canadian randomized trial of paclitaxel in relapsed ovarian cancer: high-dose versus low-dose and long versus short infusion. J Clin Oncol 1994; 12(12):2654-2666.

25. Goss PE, Ingle JN, Alés-Martínez JE, Cheung AM, Chlebowski RT, Wactawski-Wende J et al. Exemestane for breast-cancer prevention in postmenopausal women. N Engl J Med 2011; 364(25):2381-2391.

26. Ma BB, Oza A, Eisenhauer E, Stanimir G, Carey M, Chapman W et al. The activity of letrozole in patients with advanced or recurrent endometrial cancer and correlation with biological markers--a study of the National Cancer Institute of Canada Clinical Trials Group. Int J Gynecol Cancer. 2004; 14(4):650-658.

27. Pearcey R, Brundage M, Drouin P, Jeffrey J, Johnston D, Lukka H et al. Phase III trial comparing radical radiotherapy with and without cisplatin chemotherapy in patients with advanced squamous cell cancer of the cervix. J Clin Oncol 2002; 20(4):966-972. 
28. Hollinshead A, Stewart THM, Takita H, Dalbow M, Concannon J. Adjuvant specific active lung cancer immunotherapy trials. Cancer 1987; 60:1249-1262.

29. Goss PE, Ingle JN, Pritchard KI, Ellis MJ, Sledge GW, Budd GT et al. Exemestane versus anastrozole in postmenopausal women with early breast cancer: NCIC CTG MA.27--a randomized controlled phase III trial. J Clin Oncol. 2013; 31(11):1398-1404.

30. Dark GG, Calvert AH, Grimshaw R, Poole C, Swenerton K, Kaye S et al. Randomized trial of two intravenous schedules of the topoisomerase I inhibitor liposomal lurtotecan in women with relapsed epithelial ovarian cancer: a trial of the national cancer institute of Canada clinical trials group. J Clin Oncol 2005; 23(9):1859-1866.

31. Crook JM, O'Callaghan CJ, Duncan G, Dearnaley DP, Higano CS, Horwitz EM et al. Intermittent androgen suppression for rising PSA level after radiotherapy. N Engl J Med 2012; 367(10):895-903.

32. Winton T, Livingston R, Johnson D, Rigas J, Johnston M, Butts C et al. Vinorelbine plus cisplatin vs. observation in resected non-small-cell lung cancer. N Engl J Med 2005; 352(25):2589-2597.

33. Goss GD, O'Callaghan C, Lorimer I, Tsao MS, Masters GA, Jett J et al. Gefitinib versus placebo in completely resected non-small-cell lung 
cancer: results of the NCIC CTG BR19 study. J Clin Oncol. 2013;

31(27):3320-3326.

34. Murray N, Livingston RB, Shepherd FA, James K, Zee B, Langleben A et al. Randomized study of CODE versus alternating CAV/EP for extensivestage small-cell lung cancer: an intergroup study of the National Cancer Institute of Canada Clinical Trials Group and the Southwest Oncology Group. J Clin Oncol 1999:17(8):2300-2308.

35. Ackland SP, Jones M, Tu D, Simes J, Yuen J, Sargeant A et al. A metaanalysis of two randomised trials of early chemotherapy in asymptomatic metastatic colorectal cancer. Br J Cancer 2005; 93(11):1236-1243.

36. Stewart DJ, Donehower RC, Eisenhauer EA, Wainman N, Shah AK, Bonfils C et al. A phase I pharmacokinetic and pharmacodynamic study of the DNA methyltransferase 1 inhibitor MG98 administered twice weekly. Ann Oncol. 2003; 14(5):766-774.

37. Chen CI, Kouroukis CT, White D, Voralia M, Stadtmauer E, Stewart AK et al. Bortezomib is active in patients with untreated or relapsed Waldenstrom's macroglobulinemia: a phase II study of the National Cancer Institute of Canada Clinical Trials Group. J Clin Oncol. 2007; 25(12):1570-1575.

38. Chi KN, Hotte SJ, Yu EY, Tu D, Eigl BJ, Tannock I et al. Randomized phase II study of docetaxel and prednisone with or without OGX-011 in 
patients with metastatic castration-resistant prostate cancer. J Clin Oncol. 2010; 28(27):4247-4254.

39. Petrella TM, Mihalcioiu CLD, McWhirter E, Belanger K, Savage KJ, Song X et al. Final efficacy results of NCIC CTG IND.202: A randomized phase II study of recombinant interleukin-21 (rIL21) in patients with recurrent or metastatic melanoma (MM) [abstract]. J Clin Oncol (Meeting Abstracts) 2013; 31[suppl; abstr 9032].

40. Cairncross G, Macdonald D, Ludwin S, Lee D, Cascino T, Buckner J et al. Chemotherapy for anaplastic oligodendroglioma. J Clin Oncol 1994; 12(10):2013-2021.

41. Pritchard KI, Shepherd LE, Chapman JA, Norris BD, Cantin J, Goss PE et al. Randomized trial of Tamoxifen versus combined Tamoxifen and Octreotide LAR therapy in the adjuvant treatment of early-stage breast cancer in postmenopausal women: NCIC CTG MA.14. J Clin Oncol 2011; 29(29):3869-3876.

42. Burnell M, Levine MN, Chapman J-AW, Bramwell V, Gelmon K, Walley B et al. Cyclophosphamide, epirubicin, and fluorouracil versus dose-dense epirubicin and cyclophosphamide followed by paclitaxel versus doxorubicin and cyclophosphamide followed by paclitaxel in nodepositive or high-risk node-negative breast cancer. J Clin Oncol 2010; 28:77-82. 
43. Cigler T, Tu D, Yaffe MJ, Findlay B, Verma S, Johnston D et al. A randomized, placebo-controlled trial (NCIC CTG MAP1) examining the effects of letrozole on mammographic breast density and other end organs in postmenopausal women. Breast Cancer Res Treat 2010; 120(2):427435.

44. Cigler T, Richardson H, Yaffe MJ, Fabian CJ, Johnston D, Ingle JN et al. A randomized, placebo-controlled trial (NCIC CTG MAP.2) examining the effects of exemestane on mammographic breast density, bone density, markers of bone metabolism and serum lipid levels in postmenopausal women. Breast Cancer Res Treat 2011; 126(2):453-461.

45. Stewart AK, Trudel S, Bahlis NJ, White D, Sabry W, Belch A et al. A randomized phase 3 trial of thalidomide and prednisone as maintenance therapy after ASCT in patients with MM with a quality-of-life assessment: the National Cancer Institute of Canada Clinicals Trials Group Myeloma 10 Trial. Blood. 2013; 121(9):1517-1523.

46. Shustik C, Belch A, Robinson S, Rubin SH, Dolan SP, Kovacs MJ et al. A randomised comparison of melphalan with prednisone or dexamethasone as induction therapy and dexamethasone or observation as maintenance therapy in multiple myeloma: NCIC CTG MY.7. Br J Haematol. 2007; 136(2):203-211. 
47. Moore MJ, Hamm J, Dancey J, Eisenberg PD, Dagenais M, Fields A et al. Comparison of gemcitabine versus the matrix metalloproteinase inhibitor BAY12-9566 in patients with advanced or metastatic adenocarcinoma of the pancreas: a phase III trial of the National Cancer Institute of Canada Clinical Trials Group. J Clin Oncol 2003; 21(17):3296-3302.

48. Warde P, Mason M, Ding K, Kirkbride P, Brundage M, Cowan R et al. Combined androgen deprivation therapy and radiation therapy for locally advanced prostate cancer: a randomised, phase 3 trial. Lancet. 2011;378(9809):2104-2111.

49. Lofters W, Pater JL, Zee B, Dempsey E, Walde D, Moquin J et al. Phase III double-blind comparison of dolasetron mesylate and ondansetron and an evaluation of the additive role of dexamethasone in the prevention of acute and delayed nausea and vomiting due to moderately emetogenic chemotherapy. J Clin Oncol 1997; 15(8):2966-2973.

50. Paterson AH, Anderson SJ, Lembersky BC, Fehrenbacher L, Falkson CI, King KM et al. A clinical trial comparing adjuvant clodronate therapy vs. placebo in early stage breast cancer patients receiving systemic chemotherapy and/or hormonal therapy or no therapy. Lancet Oncol 2012; 13(7):734-742.

51. Fisher B, Anderson S, Bryant J, Margolese RG, Deutsch M, Fisher ER et al. Twenty-Year Follow-up of a Randomized Trial Comparing Total 
Mastectomy, Lumpectomy, and Lumpectomy Plus Irradiation For the Treatment of Invasive Breast Cancer. N Engl J Med 2002; 347(16):12331241.

52. Fisher B, Bauer M, Margolese R, Poisson R, Pilch Y, Redmond C et al. Five-Year Results of a Randomized Clinical Trial Comparing Total Mastectomy and Segmental Mastectomy With or Without Radiation in the Treatment of Breast Cancer. N Engl J Med 1985; 312:665-673.

53. Lembersky BC, Wieand HS, Petrelli NJ, O'Connell MJ, Colangelo LH, Smith RE et al. Oral uracil and tegafur plus leucovorin compared with intravenous fluorouracil and leucovorin in stage II and III carcinoma of the colon: results from National Surgical Adjuvant Breast and Bowel Project Protocol C-06. J Clin Oncol. 2006; 24(13):2059-2064.

54. Yothers G, O'Connell MJ, Allegra CJ, Kuebler JP, Colangelo LH, Petrelli NJ et al. Oxaliplatin as adjuvant therapy for colon cancer: updated results of NSABP C-07 trial, including survival and subset analyses. J Clin Oncol. 2011; 29(28):3768-3774.

55. Fisher B, Montague E, Redmond C, Deutsch M, Brown GR, Zauber et al. Findings from NSABP Protocol No. B-04-comparison of radical mastectomy with alternative treatments for primary breast cancer. I. 
Radiation compliance and its relation to treatment outcome. Cancer. 1980; 46(1):1-13.

56. Fisher B, Wolmark N, Redmond C et al. Findings from NSABP Protocol No. B-04: comparison of radical mastectomy with alternative treatments. II. The clinical and biologic significance of medial-central breast cancers. Cancer 1981; 48(8):1863-1872.

57. Fisher B, Fisher E, Redmond C, et al. Ten year results from the National Surgical Adjuvant Breast and Bowel Project (NSABP) clinical trial evaluating the use of L-Phenylalanine mustard (LPAM) in the management of primary breast cancer. J Clin Oncol. 1986; 4:929-941.

58. Fisher B, Glass A, Redmond C, Fisher ER, Barton B, Such E et al. LPhenylalanine mustard (L-PAM) in the management of primary breast cancer: an update of earlier findings and a comparison with those utilizing L-PAM plus 5-Fluorouracil (5-FU). Cancer 1977; 39:2883-2903.

59. Mueller CB, Lesperance ML . NSABP trials of adjuvant chemotherapy for breast cancer. A further look at the evidence. Ann Surg. 1991; 214(3):206-11.

60. Fisher B, Redmond C, Brown A, Fisher ER, Wolmark N, Bowman D et al. Adjuvant chemotherapy with and without tamoxifen in the treatment of primary breast cancer: 5-year results from the National Surgical Adjuvant Breast and Bowel Project Trial. J Clin Oncol. 1986;4(4):459-471. 
61. Fisher B, Brown A, Wolmark N, Fisher ER, Redmond C, Wickerham DL et al. Evaluation of the worth of corynebacterium parvum in conjunction with chemotherapy as adjuvant treatment for primary breast cancer. Eightyear results from the National Surgical Adjuvant Breast and Bowel Project B-10. Cancer. 1990; 66(2):220-227.

62. Fisher B, Bauer M, Margolese R, Poisson R, Pilch Y, Redmond C et al. Increased benefit from addition of adriamycin to adjuvant therapy for stage II breast cancer: results from NSABP protocols B-11 and B-12 [abstract]. Proceedings American Society of Clinical Oncology (Meeting Abstracts) 6:62, 1987.

63. Fisher B and Redmond C. Systemic therapy in node-negative patients: updated findings from NSABP clinical trials, J Natl Cancer Inst Monographs 1992; 11:105-116.

64. Fisher B, Dignam J, Mamounas EP, Costantino JP, Wickerham DL, Redmond C et al. Sequential methotrexate and fluorouracil for the treatment of node-negative breast cancer patients with estrogen receptornegative tumors: eight-year results from National Surgical Adjuvant Breast and Bowel Project (NSABP) B-13 and first report of findings from NSABP B-19 comparing methotrexate and fluorouracil with conventional cyclophosphamide, methotrexate, and fluorouracil. J Clin Oncol. 1996; 14(7):1982-1992. 
65. Fisher B, Dignam J, Bryant J, DeCillis A, Wickerham DL, Wolmark N et al. Five versus more than five years of tamoxifen therapy for breast cancer patients with negative lymph nodes and estrogen receptor-positive tumors. J Natl Cancer Instit 1996; 88:1529-1542.

66. Fisher B, Brown AM, Dimitrov NV, Poisson R, Redmond C, Margolese RG et al. Two months of doxorubicin-cyclophosphamide with and without interval reinduction therapy compared with 6 months of cyclophosphamide, methotrexate, and florouracil in positive-node breast cancer patients with tamoxifen-nonresponsive tumors: results the National Surgical Adjuvant Breast and Bowel project B-15. J Clin Oncol. 1990; 8(9):1483-1496.

67. Fisher B, Redmond C, Legault-Poisson S, Dimitrov NV, Brown AM, Wickerham DL et al. Postoperative chemotherapy and tamoxifen compared with tamoxifen alone in the treatment of positive-node breast cancer patients aged 50 years and older with tumors responsive to tamoxifen: results from NSABP B-16. J Clin Oncol. 1990; 8(6):10051018.

68. Fisher B, Dignam J, Wolmark N, Mamounas E, Costantino J, Poller W et al. Lumpectomy and radiation therapy for the treatment of intraductal breast cancer: findings from National Surgical Adjuvant Breast and Bowel project B-17. J Clin Oncol. 1998; 16(2):441-452. 
69. Wapnir IL, Dignam JJ, Fisher B, Mamounas EP, Anderson SJ, Julian TB et al. Long-term outcomes of invasive ipsilateral breast tumor recurrences after lumpectomy in NSABP B-17 and B-24 randomized clinical trials for DCIS. J Natl Cancer Inst. 2011; 103(6):478-488.

70. Wolmark N, Wang J, Mamounas E et al. Preoperative chemotherapy in patients with operable breast cancer: nine-year results from National Surgical Adjuvant Breast and Bowel project B-18. J Natl Cancer Inst Monogr 2001; (30):96-102.

71. Fisher B, Brown A, Mamounas E, Wieand S, Robidoux A, Margolese RG et al. Effect of preoperative chemotherapy on local-regional disease in women with operable breast cancer: findings from National Surgical Adjuvant Breast and Bowel project B-18. J Clin Oncol. 1997; 15(7):24832493.

72. Fisher B, Dignam J, Wolmark N, DeCillis A, Emir B, Wickerham DL et al. Tamoxifen and Chemotherapy for Lymph Node-Negative, Estrogen Receptor-Positive Breast Cancer. J Natl Cancer Inst 1997; 89(22):16731682.

73. Fisher B, Jeong JH, Dignam J, Anderson S, Mamounas E, Wickerham DL et al. Findings from recent National Surgical Adjuvant Breast and Bowel Project adjuvant studies in stage I breast cancer. J Natl Cancer Inst Monogr. 2001; (30):62-66. 
74. Fisher B, Anderson S, Wickerham DL, DeCillis A, Dimitrov N, Mamounas E et al. Increased intensification and total dose of cyclophosphamide in a doxorubicin-cyclophosphamide regimen for the treatment of primary breast cancer: findings from National Surgical Adjuvant Breast and Bowel project B-22. J Clin Oncol. 1997; 15(5):18581869.

75. Fisher B, Anderson S, Tan-Chiu E, Wolmark N, Wickerham DL, Fisher ER et al. Tamoxifen and chemotherapy for axillary node-negative, estrogen receptor-negative breast cancer: findings from National Surgical Adjuvant Breast and Bowel Project B-23. J Clin Oncol. 2001;19(4):931942.

76. Allred DC, Anderson SJ, Paik S, Wickerham DL, Nagtegaal ID, Swain SM et al. Adjuvant Tamoxifen Reduces Subsequent Breast Cancer in Women with Estrogen Receptor-Positive Ductal Carcinoma In Situ: A Study Based on NSABP Protocol B-24.J Clin Oncol. 2012; 30(12):12681273.

77. Fisher B, Anderson S, DeCillis A, Dimitrov N, Atkins JN, Fehrenbacher L et al. Further evaluation of intensified and increased total dose of cyclophosphamide for the treatment of primary breast cancer: findings from National Surgical Adjuvant Breast and Bowel Project B-25. J Clin Oncol. 1999;17(11):3374-3388. 
78. Smith RE, Brown AM, Mamounas EP, Anderson SJ, Lembersky BC, Atkins JH, Shibata HR, Baez L, DeFusco PA, Davila E, Tipping SJ, Bearden JD, Thirlwell MP. Randomized Trial of 3-Hour Versus 24-Hour Infusion of High-Dose Paclitaxel in Patients with Metastatic or Locally Advanced Breast Cancer: National Surgical Adjuvant Breast and Bowel Project Protocol B-26. J Clini Oncol 1999; 17(11):3403-3411.

79. Bear HD, Anderson S, Brown A, Smith R, Mamounas EP, Fisher B et al. The effect on tumor response of adding sequential preoperative docetaxel to preoperative doxorubicin and cyclophosphamide: preliminary results from National Surgical Adjuvant Breast and Bowel project protocol B-27. National Surgical Adjuvant Breast and Bowel Project Protocol B-27. J Clin Oncol 2003; 21(22):4165-4174.

80. Rastogi P, Anderson SJ, Bear HD, Geyer CE, Kahlenberg MS, Robidoux A et al. Preoperative Chemotherapy: Updates of National Surgical Adjuvant Breast and Bowel Project Protocols. J Clin Oncol. 2008; 26(5):778-785.

81. Mamounas EP1, Bryant J, Lembersky B, Fehrenbacher L, Sedlacek SM, Fisher B, Wickerham DL, Yothers G, Soran A, Wolmark N. Paclitaxel after doxorubicin plus cyclophosphamide as adjuvant chemotherapy for 
node-positive breast cancer: results from NSABP B-28. J Clin Oncol. 2005 Jun 1;23(16):3686-3696.

82. Swain SM, Land SR, Ritter MW, Costantino JP, Cecchini RS, Mamounas EP, Wolmark N, Ganz PA. Amenorrhea in premenopausal women on the doxorubicin-and-cyclophosphamide-followed-by docetaxel arm of NSABP B-30 trial. Breast Cancer Res Treat. 2009; 113(2):315-320.

83. Perez EA, Romond EH, Suman VJ, Jeong JH, Davidson NE, Geyer CE Jr et al. Four-year follow-up of trastuzumab plus adjuvant chemotherapy for operable human epidermal growth factor receptor 2-positive breast cancer: joint analysis of data from NCCTG N9831 and NSABP B-31. J Clin Oncol. 2011; 29(25):3366-3373.

84. Krag DN, Anderson SJ, Julian TB, Brown AM, Harlow SP, Costantino JP et al. Sentinel-lymph-node resection compared with conventional axillarylymph-node dissection in clinically node-negative patients with breast cancer: overall survival findings from the NSABP B-32 randomised phase 3 trial. Lancet Oncol. 2010; 11(10):927-933.

85. Paterson AH, Anderson SJ, Lembersky BC, Fehrenbacher L, Falkson CI, King KM et al. A clinical trial comparing adjuvant clodronate therapy vs. placebo in early stage breast cancer patients receiving systemic chemotherapy and/or hormonal therapy or no therapy. Lancet Oncol 2012; 13(7):734-742. 
86. Wapnir IL, Aebi S, Geyer CE, Zahrieh D, Gelber RD, Anderson SJ et al. A randomized clinical trial of Adjuvant Chemotherapy for Radically Resected Locoregional Relapse of Breast Cancer: IBCSG 27-02, BIG 102, and NSABP B-37. Clin Breast Cancer 2008; 8(3):287-292.

87. Wapnir IL, Aebi S, Gelber S, Anderson SJ, Láng I, Robidoux A et al. Progress on BIG 1-02/IBCSG 27-02/NSABP B-37, a prospective randomized trial evaluating chemotherapy after local therapy for isolated locoregional recurrences of breast cancer. Ann Surg Oncol 2008; 15(11):3227-3231.

88. Swain SM, Tang G, Geyer CE Jr, Rastogi P, Atkins JN, Donnellan PP et al. Definitive Results of a Phase III Adjuvant Trial Comparing Three Chemotherapy Regimens in Women with Operable, Node-Positive Breast Cancer: The NSABP B-38 Trial. J Clin Oncol 2013; 31(26):3197-3204.

89. Croshaw R, Kim Y, Lappinen E et al. Avoiding mastectomy: Accelerated partial breast irradiation for breast cancer patients with pacemakers or defibrillators. Ann Surg Oncol 2011; 18(12):3500-3505.

90. Kim Y, Parda DS, Trombetta MG, Colonias A, Werts ED, Miller L et al. Dosimetric comparison of partial and whole breast external beam irradiation in the treatment of early stage breast cancer. Med Phys 2007; 34(12):4640-4648. 
91. Bear HD, Tang G, Rastogi P, Geyer CE Jr, Robidoux A, Atkins JN et al. Bevacizumab added to neoadjuvant chemotherapy for breast cancer. $\mathrm{N}$ Engl J Med 2012; 366(4):310-320.

92. Mamounas EP, Lembersky B, Jeong JH, Cronin W, Harkins B, Geyer C et al. NSABP B-42: A clinical trial to determine the efficacy of five years of letrozole compared with placebo in patients completing five years of hormonal therapy consisting of an aromatase inhibitor (AI) or tamoxifen followed by an AI in prolonging disease-free survival in postmenopausal women with hormone receptor-positive breast cancer. Clin Breast Cancer 2006; 7(5):416-421.

93. Siziopikou KP, Anderson SJ, Cobleigh MA, Julian TB, Arthur DW, Zheng P et al. Preliminary Results of Centralized HER2 Testing In Ductal Carcinoma In Situ (DCIS): NSABP B-43. Breast Cancer Res Treat 2013; 142(2):415-421.

94. Smith RE, Colangelo L, Wieand HS et al. Randomized trial of adjuvant therapy in colon carcinoma: 10-year results of NSABP protocol C-01. J Natl Cancer Inst 2004; 96(15):1128-1132.

95. Wilkinson NW, Yothers G, Lopa S et al. Long-term survival results of surgery alone versus surgery plus 5-fluorouracil and leucovorin for stage II and stage III colon cancer: pooled analysis of NSABP C-01 through C- 
05. A baseline from which to compare modern adjuvant trials. Ann Surg Oncol. 2010; 17(4):959-966.

96. Wolmark N, Rockette H, Mamounas E, Jones J, Wieand S, Wickerham DL et al. Clinical trial to assess the relative efficacy of fluorouracil and leucovorin, fluorouracil and levamisole, and fluorouracil, leucovorin, and levamisole in patients with dukes' B and C carcinoma of the colon: results from National Surgical Adjuvant Breast and Bowel project C-04. J Clin Oncol 1999; 17(11):3553-3559.

97. Allegra CJ, Yothers G, O'Connell MJ, Sharif S, Petrelli NJ, Lopa SH et al. Bevacizumab in Stage II-III Colon Cancer: 5-year Update of the National Surgical Adjuvant Breast and Bowel Project C-08 Trial. J Clin Oncol. 2013; 31(3):359-364.

98. Fisher B, Wolmark N, Rockette H, Redmond C, Deutsch M, Wickerham DL et al. Postoperative adjuvant chemotherapy or radiation therapy for rectal cancer: results from NSABP protocol R-01. J Natl Cancer Inst 1988; 80(1):21-29.

99. Wolmark N, Wieand HS, Hyams DM, Colangelo L, Dimitrov NV, Romond EH et al. Randomized trial of postoperative adjuvant chemotherapy with or without radiotherapy for carcinoma of the rectum: National Surgical Adjuvant Breast and Bowel Project Protocol R-02. J Natl Cancer Inst 2000; 92(5):388-396. 
100. Roh MS, Colangelo LH, O'Connell MJ, Yothers G, Deutsch M, Allegra CJ et at. Preoperative multimodality therapy improves disease-free survival in patients with carcinoma of the rectum: NSABP R-03. J Clin Oncol. 2009; 27(31):5124-5130.

101. O'Connell MJ, Colangelo LH, Beart RW, Petrelli NJ, Allegra CJ, Sharif S et al. Capecitabine and oxaliplatin in the preoperative multimodality treatment of rectal cancer: surgical end points from National Surgical Adjuvant Breast and Bowel Project trial R-04. J Clin Oncol. 2014; (18):1927-1934.

102. Fisher B, Costantino J, Wickerham DL, Cecchini RS, Cronin WM, Robidoux A. Tamoxifen for the prevention of breast cancer: current Status of the National Surgical Adjuvant Breast and Bowel project P-1 study. J Natl Cancer Inst. 2005; 97(22):1652-1662.

103. Vogel VG, Costantino JP, Wickerham DL, Cronin WM, Cecchini RS, Atkins JN et al. Update of the National Surgical Adjuvant Breast and Bowel project study of tamoxifen and raloxifene (STAR) P-2 trial: preventing breast cancer. Cancer Prev Res 2010; 3(6):696-706.

104. Corn BW, Wexler ID, Sunthralingam M et al. Globalization of the RTOG: Implementation of a model for service expansion and public health improvement. J Clin Oncol 2008; 26:1160-1166. 
105. Corn BW, Symon Z, Gamzu R: The state of radiotherapy in the state of Israel. Int J Radiat Oncol Biol Phys 2014; In Press.

106. Stupp R, Mason WP, van den Bent MJ et al. Radiotherapy plus concomitant and adjuvant temozolomide for glioblastoma. N Engl J Med 2005; 352;987-996.

107. Gore EM, Bae K, Wong SJ, Sun A, Bonner JA, Schild SE et al. Phase III comparison of prophylactic cranial irradiation versus observation in patients with locally advanced non-small-cell lung cancer: primary analysis of radiation therapy oncology group study RTOG 0214. J Clin Oncol 2011; 29(3):272-278.

108. Gondi V, Paulus R, Bruner DW, Meyers CA, Gore EM, Wolfson A et al: Decline in tested and self- reported cognitive functioning after PCI for lung cancer: Pooled secondary analysis of RTOG 0212 and 0214. Int J Radiat Oncol Biol Phys 2013 86: 656-664.

109. Gore EM. RTOG 0214: A phase III comparison of PCI vs. Observation in patients with locally advanced non-small cell lung cancer. Clin Adv Hematol Oncol 2005 3:625-626.

110. Forde E, Bromley R, Kneebone A et al. A class solution of volumetric modulated arc therapy planning in post-prostatectomy radiation. Med Dosim 2014 39: 261-265. 
111. Lee NY, Zhang Q, Pfister DG, Kim J, Garden AS, Mechalakos J et al. Addition of bevacizumab to standard chemoradiation for locoregionally advanced nas172-80opharyngeal carcinoma (RTOG 0615): a phase 2 multi-institutional trial. Lancet Oncol 2012; 13(6):172-180.

112. Chen GP, Liu F, White J, Vicini FA, Freedman GM, Arthur DW et al. A planning comparison of 7 irradiation options allowed in RTOG 1005 for early-stage breast cancer. Med Dosim 2014 Aug 22. pii: S09583947(14)00083-1. doi: 10.1016/j.meddos.2014.06.007. [Epub ahead of print]

113. Sperduto PW, Wang M, Robins HI, Schell MC, Werner-Wasik M, Komaki $\mathrm{R}$ et al. A phase 3 trial of whole brain radiation therapy and stereotactic radiosurgery alone versus WBRT and SRS with temozolomide or erlotinib for non-small cell lung cancer and 1 to 3 brain metastases: Radiation Therapy Oncology Group 0320. Int J Radiat Oncol Biol Phys 2013; 85(5):1312-1318.

114. Wen B, Hsu H, Formenti-Ujlaki GF Lymberis S, Magnolfi C, Zhao X et al. Prone accelerated partial breast irradiation after breast-conserving surgery: Compliance to the dosimetry requirements of RTOG 0413. Int J Radiat Oncol Biol Phys 2012 84: 910-916. 
115. Wojcicka JB, Lasher DE, Malcom R et al. Clinical and Dosimetric experience with MammoSite-based brachytherapy under RTOG 0413. J Appl Clin Med Phys 2007 8(4):2654-2656.

116. Gilbert MR, Wang M, Aldape KD, Stupp R, Hegi ME, Jaeckle KA et al. Dose-dense temozolomide for newly diagnosed glioblastoma: a randomized phase III clinical trial. J Clin Oncol 2013; 31(32):4085-4091.

117. Krauze AV, Won M, Graves C, Corn BW, Muanza TM, Howard SP et al. Predictive value of tumor recurrence using urinary vascular endothelial factor levels in patients receiving radiotherapy for GBM. Biomark Res 2013 Oct $31 ; 1(1): 29$.

118. Boxerman JL, Zhang Z, Safriel Y, Larvie M, Snyder BS, Jain R et al. Early post-bevacizumab progression on contrast-enhanced MRI as a prognostic marker for overall survival in recurrent glioblastoma: results from the ACRIN 6677/RTOG 0625 Central Reader Study. Neuro Oncol 2013; 15(7):945-954.

119. Ratai EM, Zhang Z, Snyder BS, Boxerman JL, Safriel Y, McKinstry RC et al. Magnetic resonance spectroscopy as an early indicator of response to anti-angiogenic therapy in patients with recurrent glioblastoma: RTOG 0625/ACRIN 6677. Neuro Oncol 2013; 15(7):936-944. 
120. Ryu S, Pugh SL, Gerszten PC, Yin FF, Timmerman RD, Hitchcock YJ et al: RTOG 0631 phase 2/3 study of image guided stereotactic radiosurgery for localized spine metastases: Phase 2 results. Pract Radiat Oncol 2014: 4: 76-81.

121. Ryu S, Pugh SL, Gerszten PC, Yin FF, Timmerman RD, Hitchcock YJ et al. RTOG 0631 Phase II/III Study of Image-Guided Stereotactic Radiosurgery for Localized (1-3) Spine Metastases: Phase II Results. Int J Radiat Oncol Biol Phys 2011; 81(2):S131-S132.

122. Gilbert MR, Dignam JJ, Armstrong TS, Wefel JS, Blumenthal DT, Vogelbaum MA et al. A randomized trial of bevacizumab for newly diagnosed glioblastoma. N Engl J Med 2014; 370(8):699-708.

123. Chinnaiyan P, Won M, Wen PY, Rojiani AM, Wendland M, Dipetrillo TA et al. RTOG 0913: a phase 1 study of daily everolimus (RAD001) in combination with radiation therapy and temozolomide in patients with newly diagnosed glioblastoma. Int J Radiat Oncol Biol Phys 2013; 86(5):880-884.

124. Machtay M, Duan F, Siegel BA, Snyder BS, Gorelick JJ, Reddin JS et al. Prediction of survival by [18F]fluorodeoxyglucose positron emission tomography in patients with locally advanced non-small-cell lung cancer undergoing definitive chemoradiation therapy: results of the ACRIN 6668/RTOG 0235 trial. J Clin Oncol. 2013; 31(30):3823-3830. 
125. Schefter T, Winter K, Kwon JS, Stuhr K, Balaraj K, Yaremko BP et al. RTOG 0417: efficacy of bevacizumab in combination with definitive radiation therapy and cisplatin chemotherapy in untreated patients with locally advanced cervical carcinoma. Int J Radiat Oncol Biol Phys 2014 88(1):101-105.

126. Schefter T, Winter K, Kwon JS, Stuhr K, Balaraj K, Yaremko BP et al. A phase II study of Bevacizumab in combination with definitive radiotherapy and Cisplatin chemotherapy in untreated patients with locally advanced cervical carcinoma: Preliminary results of RTOG 0417. Int J Radiat Oncol Biol Phys 2012 83(4): 1179-1184.

127. Blanke CD, Rankin C, Demetri GD, Ryan CW, von Mehren M, Benjamin RS et al. Phase III randomized, intergroup trial assessing imatinib mesylate at two dose levels in patients with unresectable or metastatic gastrointestinal stromal tumors expressing the kit receptor tyrosine kinase: S0033. J Clin Oncol 2008; 26(4):626-632.

128. Hussain M, Tangen C, Berry DL, Higano C, Crawford ED, Liu G et al. Intermittent versus continuous androgen deprivation in prostate cancer. $\mathrm{N}$ Engl J Med 2013; 368(14):1314-1325.

129. Lippman SM, Klein EA, Goodman PJ, Lucia MS, Thompson IM, Ford LG, et al. Effect of selenium and vitamin E on risk of prostate cancer and 
other cancers: the selenium and vitamin E cancer prevention trial (SELECT). JAMA 2009; 301(1):39-51.

130. Klein EA, Thompson IM, Tangen C, Crowley J, Lucia MS, Goodman P et al. Vitamin E and the risk of prostate cancer: updated results of the selenium and vitamin E cancer prevention trial (SELECT). JAMA 2011; 306(14):1549-1556.

131. Greenberg ER, Anderson GL, Morgan DR, Torres J, Chey WD, Bravo LE et al. 14-day triple, 5-day concomitant, and 10-day sequential therapies for helicobacter pylori infection in seven Latin American sites: a randomised trial. Lancet 2011; 378(9790):507-514.

132. Morgan D, Torres J, Sexton R, Herrero R, Salazar-Martinez E, Greenberg ER et al. Risk of recurrent Helicobacter pylori infection 1 year after initial eradication therapy in 7 Latin American communities. JAMA 2013; 309(6):578-586.

133. Petersdorf SH, Kopecky KJ, Slovak M, Willman C, Nevil T, Brandwein J et al. A phase III study of the addition of gemtuzumab ozogamicin during induction and postconsolidation therapy in younger patients with acute myeloid leukemia. Blood 2013; 121(24):4854-4860.

134. Philip PA, Benedetti J, Corless CL, Wong R, O’Reilly EM, Flynn PJ et al. Phase III study comparing gemcitabine plus cetuximab versus gemcitabine in patients with advanced pancreatic adenocarcinoma: Southwest 
Oncology Group-directed intergroup trial S0205. J Clin Oncol 2010; 28(22):3605-3610.

135. Coltman C Jr, Jones SE, Grozea PN, DePersio, EJ, Dixon DO. Bleomycin in combination with MOPP in the management of advanced Hodgkin’s disease: A Southwest Oncology Group experience. In: BI Sikic, M Rozencweig, SK Carter, eds. Bleomycin Chemotherapy. New York: Academic Press Inc., Harcourt Brace Jovanovitch; 1985. Chap ii, pp. 137153.

136. Budd GT, Barlow W, Moore HCF, Hobday T, Stewart JA, Isaacs C et al. SWOG S0221: A phase III trial comparing chemotherapy schedules in high-risk early breast cancer. J Clin Oncol, In press.

137. Mehta R, Barlow W, Albain K, Vandenberg T, Dakhil S, Tirumali N et al. Combination anastrozole and fulvestrant in metastatic breast in metastatic breast cancer. N Engl J Med 2012; 367(5):435-444.

138. Dana BW, Dahlberg S, Nathwani BN et al. Long-term follow-up of patients with low-grade malignant lymphomas treated with doxorubicinbased chemotherapy or chemoimmunotherapy. Clin Oncol. 1993; 11(4):644-651.

139. Miller TP, Dahlberg S. Treatment of diffuse large-cell lymphoma: A summary of outcome for patients treated by the Southwest Oncology Group. Cancer Treat Res 1993; 66:53-63. 
140. Rivkin SE, Green S, Metch B, Cruz AB, Abeloff MD, Jewell WR et al. Adjuvant CMFVP versus tamoxifen versus concurrent CMFVP and tamoxifen for postmenopausal, node-positive and estrogen receptorpositive breast cancer patients: A Southwest Oncology Group study. J Clin Oncol 1994; 12(10):2078-2085.

141. Rivkin SE, Green S, Metch B, Jewell WR, JJ Costanzi JJ Altman SJ et al. One versus 2 years of CMFVP adjuvant chemotherapy in axillary nodepositive and estrogen receptor-negative patients: A Southwest Oncology Group study. Rivkin SE, Green S, Metch B, Jewell WR, JJ Costanzi JJ Altman SJ et al. J Clin Oncol 1993; 11(9):1710-1716.

142. Alberts DS, Kronmal R, Baker LH Stock-Novack DL, Surwit EA, Boutselis JG et al. Phase II randomized trial of cisplatin chemotherapy regimens in the treatment of recurrent or metastatic squamous cell cancer of the cervix: A Southwest Oncology Group study. J Clin Oncol 1987; 5(11):1791-1795.

143. Wozniak AJ, Samson MK, Shah NT, Crawford ED, Ford CD, Altman SJ et al. A randomized trial of cis-platinum, vinblastine, and bleomycin vs. vinblastine, cisplatin, and etoposide in the treatment of advanced germ cell tumors of the testis: A Southwest Oncology Group study. J Clin Oncol 1991; 9(1):70-76. 
144. Grossman HB, Natale RB, Tangen CM; Speights VO, Vogelzang NJ, Trump DL et al. Neoadjuvant chemotherapy plus cystectomy compared with cystectomy alone for locally advanced bladder cancer. N Engl J Med 2003; 349(9):859-866.

145. Kelsen DP, Ginsberg R, Pajak TF, Sheahan DG, Gunderson L, Mortimer J et al. Chemotherapy followed by surgery compared with surgery alone for localized esophageal cancer. N Engl J Med 1998; 339(27):1979-1984.

146. Peters WP, Rosner GL, Vredenburgh JJ, Shpall EJ, Crump M, Richardson PG et al. Prospective, randomized comparison of high-dose chemotherapy with stem-cell support versus intermediate-dose chemotherapy after surgery and adjuvant chemotherapy in women with high-risk primary breast cancer: a report of CALGB 9082, SWOG 9114, and NCIC MA-13. J Clin Oncol 2005; 23(10):2191-2200.

147. Smalley SR; Benedetti JK; Williamson SK; Robertson JM; Estes NC; Maher T et al. Phase III trial of fluorouracil-based chemotherapy regimens plus radiotherapy in postoperative adjuvant rectal cancer: GI INT 0144. J Clin Oncol 2006; 24(22):3542-3547.

148. Barlogie B, Kyle RA, Anderson KC, Greipp PR, Lazarus HM, Hurd DD et al. Standard chemotherapy compared with high-dose chemoradiotherapy for multiple myeloma: final results of phase III US Intergroup Trial S9321. J Clin Oncol 2006; 24(6):929-936. 
149. Kuhn J, Rizzo J, Chang S, Schold C, Spence A, Berger M et al. Effects of anticonvulsants (ACs) on the pharmacokinetics (PK) and metabolic profile of paclitaxel [abstract]. J Clin Oncol (Meeting Abstracts). 1997; 16:224a(\#787).

150. Stiff P, Unger J, Cook J, Constine L, Couban S, Stewart D et al. Autologous transplant as consolidation for aggressive non-hodgkin's lymphoma. N Engl J Med 2013; 369(18):1681-1690.

151. Pisters MW, Vallieres E, Crowley J, Franklin W, Bunn P, Ginsberg RJ et al. Surgery with or without preoperative paclitaxel and carboplatin in early-stage non-small cell lung cancer: Southwest Oncology Group S9900, an intergroup, randomized, phase III trial. J Clin Oncol 2010; 28(11):1843-1849.

152. Rivkin SE, Green S, Lew D, Costanzi JJ, Athens JW, Osborne CK et al. Adjuvant chemotherapy with cyclophosphamide, methotrexate, and 5fluorouracil, vincristine, and prednisone compared with single-agent Lphenylalanine mustard for patients with operable breast carcinoma and positive axillary lymph nodes 20 year results of a Southwest Oncology Group study. Cancer 2003; 97(1):21-29.

153. Tranum BL, Dixon D, Quagliana J, Neidhart J, Balcerzak SP, Costanzi JH et al. Lack of benefit of adjunctive chemotherapy in stage I malignant 
melanoma: a Southwest Oncology Group Study. Cancer Treat Rep 1987; 71(6):643-644.

154. Baker LH, Frank J, Fine G, Balcerzak SP, Stephens RL, Stuckey WJ et al. Combination chemotherapy using adriamycin, DTIC, cyclophosphamide, and actinomycin-D for advanced soft tissue sarcomas: A randomized comparative trial. A Phase III, Southwest Oncology Group study. J Clin Oncol 1987; 5(6):851-861.

155. Saiki JH, Baker LH, Rivkin SE, Shahbender S, Fletcher WS, Athens JW et al. A useful high-dose intermittent schedule of adriamycin and DTIC in the treatment of advanced sarcomas. Cancer 1986; 58(10):2196-2197.

156. Grose WE, Lehane DE, Dixon DO et al. Comparison of methotrexate and cisplatin for patients with advanced squamous cell carcinoma of the head and neck region: A Southwest Oncology Group study. Cancer Treat Rep 1985; 69:577-581.

157. Smalley S, Benedetti J, Blanke C, Haller D, Hundahl S, Estes N et al. Updated analysis of SWOG-directed Intergroup study 0116: a phase III trial of adjuvant radiochemotherapy versus observation following curative gastric resection (CALGB-9195; ECOG-6290; NCCTG-90-41; RTOG 9018 and SWOG-9008]. J Clin Oncol 2012; 30(19):2327-2333.

158. Macdonald JS, Smalley SR, Benedetti J, Hundahl SA, Estes NC, Stemmermann GN et al. Chemoradiotherapy after surgery compared with 
surgery alone for adenocarcinoma of the stomach or gastroesophageal junction. 2001; N Engl J Med 345(10):725-730.

159. Hewlett JS, Chen T, Balcerzak SP et al. High rate of long-term survival in adult acute leukemia following ten-day chemotherapy (OAP) induction. Maintenance with chemotherapy or chemotherapy plus BCG vaccine. Archives of Internal Medicine 1985; 145:1006-1012.

160. McCredie KB, Hewlett JS, Kennedy A. The chemoimmunotherapy of acute leukemia (CIAL). A cooperative group study [abstract]. J Clin Oncol (Meeting Abstracts) \#C-11, 1976:239.

161. Moore HCF, Unger JM, Phillips K-A, Boyle F, Hitre E, Porter D et al. Phase III Trial (Prevention of Early Menopause Study [POEMS]-SWOG S0230) of LHRH Analog during Chemotherapy to Reduce Ovarian Failure in Early Stage, Hormone-Receptor Negative Breast Cancer: An International Intergroup Trial of SWOG, IBCSG, ECOG, CALGB (Alliance) [abstract]. J Clin Oncol (Meeting Abstracts) 2014; 32:5s (suppl; abstr LBA505).

162. Alberts SR, Sargent DJ, Nair S, Mahoney MR, Mooney M, Thibodeau SN, Smyrk TC, Sinicrope FA, Chan E, Gill S, Kahlenberg MS, Shields AF, Quesenberry JT, Webb TA, Farr GH, Jr, Pockaj BA, Grothey A, and Goldberg RM, Effect of oxaliplatin, fluorouracil, and leucovorin with or 
without cetuximab on survival among patients with resected stage III colon cancer: a randomized trial. JAMA 2012; 307(13):1383-1393.

163. Becker H, Marcucci G, Maharry K, Radmacher MD, Mrozek K, Margeson D, Whitman SP, Wu YZ, Schwind S, Paschka P, Powell BL, Carter TH, Kolitz JE, Wetzler M, Carroll AJ, Baer MR, Caligiuri MA, Larson RA, and Bloomfield CD, Favorable prognostic impact of NPM1 mutations in older patients with cytogenetically normal de novo acute myeloid leukemia and associated gene- and microRNA-expression signatures: a Cancer and Leukemia Group B study. J Clin Oncol 2010; 28(4):596-604.

164. Bertagnolli MM, Redston M, Compton CC, Niedzwiecki D, Mayer RJ, Goldberg RM, Colacchio TA, Saltz LB, and Warren RS, Microsatellite instability and loss of heterozygosity at chromosomal location 18q: prospective evaluation of biomarkers for stages II and III colon cancer--a study of CALGB 9581 and 89803. J Clin Oncol 2011; 29(23):3153-3162.

165. Dematteo RP, Ballman KV, Antonescu CR, Maki RG, Pisters PW, Demetri GD, Blackstein ME, Blanke CD, Von Mehren M, Brennan MF, Patel S, Mccarter MD, Polikoff JA, Tan BR, and Owzar K, Adjuvant imatinib mesylate after resection of localised, primary gastrointestinal stromal tumour: a randomised, double-blind, placebo-controlled trial. Lancet 2009; 373(9669):1097-1104. 
166. Dueck AC, Reinholz MM, Geiger XJ, Tenner KS, Ballman KV, Jenkins RB, Riehle D, Chen B, Mccullough AE, Davidson NE, Martino S, Sledge GW, Kaufman PA, Kutteh LA, Gralow J, Harris L, Ingle JN, Lingle W, and Perez EA, Impact of c-MYC protein expression on outcome of patients with early-stage HER2+ breast cancer treated with adjuvant trastuzumab; NCCTG (Alliance) N9831. Clin Cancer Res 2013; 19(20):5798-5807.

167. Fernando HC, Landreneau RJ, Mandrekar SJ, Nichols FC, Hillman SL, Heron DE, Meyers BF, DiPetrillo TA, Jones DR, Starnes SL, Tan AD, Daly BDT, and Putnam JB, Impact of Brachytherapy on Local Recurrence Rates After Sublobar Resection: Results From ACOSOG Z4032 (Alliance), a Phase III Randomized Trial for High-Risk Operable NonSmall-Cell Lung Cancer. J Clin Oncol 2014; 32 (23):2456-2462.

168. Fernando HC and Timmerman R, American College of Surgeons Oncology Group Z4099/Radiation Therapy Oncology Group 1021: a randomized study of sublobar resection compared with stereotactic body radiotherapy for high-risk stage I non-small cell lung cancer. J Thorac Cardiovasc Surg 2012; 144(3):S35-38.

169. Foster NR, Qi Y, Shi Q, Krook JE, Kugler JW, Jett JR, Molina JR, Schild SE, Adjei AA, and Mandrekar SJ, Tumor response and progression-free survival as potential surrogate endpoints for overall survival in extensive 
stage small-cell lung cancer: findings on the basis of North Central Cancer Treatment Group trials. Cancer 2011; 117(6):1262-1271.

170. Furman RR, Grossbard ML, Johnson JL, Pecora AL, Cassileth PA, Jung S-H, Peterson BA, Nadler LM, Freedman A, Bayer R-L, Bartlett NL, Hurd DD, and Cheson BD, A phase III study of anti-B4-blocked ricin as adjuvant therapy post-autologous bone marrow transplant: CALGB 9254. Leuk Lymphoma 2011; 52(4):587-596.

171. Havelange V, Ranganathan P, Geyer S, Nicolet D, Huang X, Yu X, Volinia S, Kornblau SM, Andreeff M, Croce CM, Marcucci G, Bloomfield CD, and Garzon R, Implications of the miR-10 family in chemotherapy response of NPM1-mutated AML. Blood 2014; 123(15):2412-2415.

172. Hickey CJ, Schwind S, Radomska HS, Dorrance AM, Santhanam R, Mishra A, Wu YZ, Alachkar H, Maharry K, Nicolet D, Mrozek K, Walker A, Eiring AM, Whitman SP, Becker H, Perrotti D, Wu LC, Zhao X, Fehniger TA, Vij R, Byrd JC, Blum W, Lee LJ, Caligiuri MA, Bloomfield CD, Garzon R, and Marcucci G, Lenalidomide-mediated enhanced translation of C/EBPalpha-p30 protein upregulates expression of the antileukemic microRNA-181a in acute myeloid leukemia. Blood 2013; 121(1):159-169. 
173. Kim GP, Sargent DJ, Mahoney MR, Rowland KM, Jr, Philip PA, Mitchell E, Mathews AP, Fitch TR, Goldberg RM, Alberts SR, and Pitot HC, Phase III noninferiority trial comparing irinotecan with oxaliplatin, fluorouracil, and leucovorin in patients with advanced colorectal carcinoma previously treated with fluorouracil: N9841. J Clin Oncol 2009; 27(17):2848-2854.

174. Kolitz JE, George SL, Marcucci G, Vij R, Powell BL, Allen SL, Deangelo DJ, Shea TC, Stock W, Baer MR, Hars V, Maharry K, Hoke E, Vardiman JW, Bloomfield CD, and Larson RA, P-glycoprotein inhibition using valspodar (PSC-833) does not improve outcomes for patients younger than age 60 years with newly diagnosed acute myeloid leukemia: Cancer and Leukemia Group B study 19808. Blood 2010; 116(9):1413-1421.

175. Langer C, Marcucci G, Holland KB, Radmacher MD, Maharry K, Paschka P, Whitman SP, Mrozek K, Baldus CD, Vij R, Powell BL, Carroll AJ, Kolitz JE, Caligiuri MA, Larson RA, and Bloomfield CD, Prognostic importance of MN1 transcript levels, and biologic insights from MN1associated gene and microRNA expression signatures in cytogenetically normal acute myeloid leukemia: a cancer and leukemia group B study. J Clin Oncol 2009; 27(19):3198-3204.

176. Loprinzi CL, Qin R, Dakhil SR, Fehrenbacher L, Flynn KA, Atherton P, Seisler D, Qamar R, Lewis GC, and Grothey A, Phase III Randomized, Placebo-Controlled, Double-Blind Study of Intravenous Calcium and 
Magnesium to Prevent Oxaliplatin-Induced Sensory Neurotoxicity (N08CB/Alliance). J Clin Oncol 2014; 32(10):997-1005.

177. Marcucci G, Maharry K, Radmacher MD, Mrozek K, Vukosavljevic T, Paschka P, Whitman SP, Langer C, Baldus CD, Liu CG, Ruppert AS, Powell BL, Carroll AJ, Caligiuri MA, Kolitz JE, Larson RA, and Bloomfield CD, Prognostic significance of, and gene and microRNA expression signatures associated with CEBPA mutations in cytogenetically normal acute myeloid leukemia with high-risk molecular features: a Cancer and Leukemia Group B Study. J Clin Oncol 2008; 26(31):5078-5087.

178. Marcucci G, Maharry K, Wu YZ, Radmacher MD, Mrozek K, Margeson D, Holland KB, Whitman SP, Becker H, Schwind S, Metzeler KH, Powell BL, Carter TH, Kolitz JE, Wetzler M, Carroll AJ, Baer MR, Caligiuri MA, Larson RA, and Bloomfield CD, IDH1 and IDH2 gene mutations identify novel molecular subsets within de novo cytogenetically normal acute myeloid leukemia: a Cancer and Leukemia Group B study. J Clin Oncol 2010; 28(14):2348-2355.

179. Marcucci G, Maharry KS, Metzeler KH, Volinia S, Wu Y-Z, Mrozek K, Nicolet D, Kohlschmidt J, Whitman SP, Mendler JH, Schwind S, Becker H, Eisfeld A-K, Carroll AJ, Powell BL, Kolitz JE, Garzon R, Caligiuri MA, Stone RM, and Bloomfield CD, Clinical Role of microRNAs in 
Cytogenetically Normal Acute Myeloid Leukemia: miR-155 Upregulation Independently Identifies High-Risk Patients. J Clin Oncol 2013;

31(17):2086-2093.

180. Marcucci G, Radmacher MD, Maharry K, Mrozek K, Ruppert AS, Paschka P, Vukosavljevic T, Whitman SP, Baldus CD, Langer C, Liu CG, Carroll AJ, Powell BL, Garzon R, Croce CM, Kolitz JE, Caligiuri MA, Larson RA, and Bloomfield CD, MicroRNA expression in cytogenetically normal acute myeloid leukemia. N Engl J Med 2008; 358(18):1919-1928.

181. Mendler JH, Maharry K, Radmacher MD, Mrozek K, Becker H, Metzeler KH, Schwind S, Whitman SP, Khalife J, Kohlschmidt J, Nicolet D, Powell BL, Carter TH, Wetzler M, Moore JO, Kolitz JE, Baer MR, Carroll AJ, Larson RA, Caligiuri MA, Marcucci G, and Bloomfield CD, RUNX1 Mutations Are Associated With Poor Outcome in Younger and Older Patients With Cytogenetically Normal Acute Myeloid Leukemia and With Distinct Gene and MicroRNA Expression Signatures. J Clin Oncol 2012; 30(25):3109-3118.

182. Metzeler KH, Becker H, Maharry K, Radmacher MD, Kohlschmidt J, Mrozek K, Nicolet D, Whitman SP, Wu YZ, Schwind S, Powell BL, Carter TH, Wetzler M, Moore JO, Kolitz JE, Baer MR, Carroll AJ, Larson RA, Caligiuri MA, Marcucci G, and Bloomfield CD, ASXL1 mutations identify a high-risk subgroup of older patients with primary 
cytogenetically normal AML within the ELN Favorable genetic category. Blood 2011; 118(26):6920-6929.

183. Metzeler KH, Hummel M, Bloomfield CD, Spiekermann K, Braess J, Sauerland MC, Heinecke A, Radmacher M, Marcucci G, Whitman SP, Maharry K, Paschka P, Larson RA, Berdel WE, Buchner T, Wormann B, Mansmann U, Hiddemann W, Bohlander SK, and Buske C, An 86-probeset gene-expression signature predicts survival in cytogenetically normal acute myeloid leukemia. Blood 2008; 112(10):4193-4201.

184. Metzeler KH, Maharry K, Kohlschmidt J, Volinia S, Mrozek K, Becker H, Nicolet D, Whitman SP, Mendler JH, Schwind S, Eisfeld A-K, Wu YZ, Powell BL, Carter TH, Wetzler M, Kolitz JE, Baer MR, Carroll AJ, Stone RM, Caligiuri MA, Marcucci G, and Bloomfield CD, A stem cell-like gene expression signature associates with inferior outcomes and a distinct microRNA expression profile in adults with primary cytogenetically normal acute myeloid leukemia. Leukemia 2013; 27(10): 2023-2031.

185. Metzeler KH, Maharry K, Radmacher MD, Mrozek K, Margeson D, Becker H, Curfman J, Holland KB, Schwind S, Whitman SP, Wu YZ, Blum W, Powell BL, Carter TH, Wetzler M, Moore JO, Kolitz JE, Baer MR, Carroll AJ, Larson RA, Caligiuri MA, Marcucci G, and Bloomfield CD, TET2 mutations improve the new European LeukemiaNet risk 
classification of acute myeloid leukemia: a Cancer and Leukemia Group B study. J Clin Oncol 2011; 29(10):1373-81.

186. Mrozek K, Marcucci G, Nicolet D, Maharry KS, Becker H, Whitman SP, Metzeler KH, Schwind S, Wu YZ, Kohlschmidt J, Pettenati MJ, Heerema NA, Block AW, Patil SR, Baer MR, Kolitz JE, Moore JO, Carroll AJ, Stone RM, Larson RA, and Bloomfield CD, Prognostic significance of the European LeukemiaNet standardized system for reporting cytogenetic and molecular alterations in adults with acute myeloid leukemia. J Clin Oncol 2012; 30(36):4515-4523.

187. Muss HB, Berry DA, Cirrincione CT, Theodoulou M, Mauer AM, Kornblith AB, Partridge AH, Dressler LG, Cohen HJ, Becker HP, Kartcheske PA, Wheeler JD, Perez EA, Wolff AC, Gralow JR, Burstein HJ, Mahmood AA, Magrinat G, Parker BA, Hart RD, Grenier D, Norton L, Hudis CA, and Winer EP, Adjuvant chemotherapy in older women with early-stage breast cancer. N Engl J Med 2009; 360(20):2055-2065.

188. Neubauer A, Maharry K, Mrozek K, Thiede C, Marcucci G, Paschka P, Mayer RJ, Larson RA, Liu ET, and Bloomfield CD, Patients with acute myeloid leukemia and RAS mutations benefit most from postremission high-dose cytarabine: a Cancer and Leukemia Group B study. J Clin Oncol 2008; 26(28):4603-4609. 
189. Niederwieser C, Kohlschmidt J, Volinia S, Whitman SP, Metzeler KH, Eisfeld A-K, Maharry K, Yan P, Frankhouser D, Becker H, Schwind S, Carroll AJ, Nicolet D, Mendler JH, Curfman JP, Wu Y-Z, Baer MR, Powell BL, Kolitz JE, Moore JO, Carter TH, Bundschuh R, Larson RA, Stone RM, Mrózek K, Marcucci G, and Bloomfield CD, Prognostic and biologic significance of DNMT3B expression in older patients with cytogenetically normal primary acute myeloid leukemia. Leukemia 2014 Sep 10. doi: 10.1038/leu.2014.267. [Epub ahead of print].

190. Niedzwiecki D, Bertagnolli MM, Warren RS, Compton CC, Kemeny NE, Benson AB, 3rd, Eckhardt SG, Alberts S, Porjosh GN, Kerr DJ, Fields A, Rougier P, Pipas JM, Schwartz JH, Atkins J, O'Rourke M, Perry MC, Goldberg RM, Mayer RJ, and Colacchio TA, Documenting the natural history of patients with resected stage II adenocarcinoma of the colon after random assignment to adjuvant treatment with edrecolomab or observation: results from CALGB 9581. J Clin Oncol 2011; 29(23):31463152.

191. Norton N, Olson RM, Pegram M, Tenner K, Ballman KV, Clynes R, Knutson KL, and Perez EA, Association Studies of Fc $\gamma$ Receptor Polymorphisms with Outcome in HER2+ Breast Cancer Patients Treated with Trastuzumab in NCCTG (Alliance) Trial N9831. Cancer Immunol Res 2014; 2(10);962-969. 
192. Okuno SH, Delaune R, Sloan JA, Foster NR, Maurer MJ, Aubry MC, Rowland KM, Jr, Soori GS, Nikcevich DA, Kardinal CG, Northfelt DW, and Adjei AA, A phase 2 study of gemcitabine and epirubicin for the treatment of pleural mesothelioma: a North Central Cancer Treatment Study, N0021. Cancer 2008; 112(8):1772-1779.

193. Olson JA, Budd GT, Carey LA, Harris LA, Esserman LJ, Fleming GF, Marcom PK, Leight GS, Giuntoli T, Commean P, Bae K, Luo J, and Ellis MJ, Improved Surgical Outcomes for Breast Cancer Patients Receiving Neoadjuvant Aromatase Inhibitor Therapy: Results from a Multicenter Phase II Trial. J Am Coll Surg 2009; 208(5);906-916.

194. Paschka P, Marcucci G, Ruppert AS, Whitman SP, Mrozek K, Maharry K, Langer C, Baldus CD, Zhao W, Powell BL, Baer MR, Carroll AJ, Caligiuri MA, Kolitz JE, Larson RA, and Bloomfield CD, Wilms' tumor 1 gene mutations independently predict poor outcome in adults with cytogenetically normal acute myeloid leukemia: a cancer and leukemia group B study. J Clin Oncol 2008; 26(28): 4595-4602.

195. Perez EA, Dueck AC, McCullough AE, Chen B, Geiger XJ, Jenkins RB, Lingle WL, Davidson NE, Martino S, Kaufman PA, Kutteh LA, Sledge GW, Harris LN, Gralow JR, and Reinholz MM, Impact of PTEN Protein Expression on Benefit From Adjuvant Trastuzumab in Early-Stage Human Epidermal Growth Factor Receptor 2-Positive Breast Cancer in the North 
Central Cancer Treatment Group N9831 Trial. J Clin Oncol 2013;

31(17):2115-2122.

196. Perez EA, Dueck AC, McCullough AE, Reinholz MM, Tenner KS, Davidson NE, Gralow J, Harris LN, Kutteh LA, Hillman DW, Jenkins RB, and Chen B, Predictability of Adjuvant Trastuzumab Benefit in N9831 Patients Using the ASCO/CAP HER2-Positivity Criteria. J Natl Cancer Inst 2012; 104(2):159-162.

197. Perez EA, Press MF, Dueck AC, Jenkins RB, Kim C, Chen B, Villalobos I, Paik S, Buyse M, Wiktor AE, Meyer R, Finnigan M, Zujewski J, Shing M, Stern HM, Lingle WL, Reinholz MM, and Slamon DJ. Immunohistochemistry and fluorescence in situ hybridization assessment of HER2 in clinical trials of adjuvant therapy for breast cancer (NCCTG N9831, BCIRG 006, and BCIRG 005). Breast Cancer Res Treat 2013; 138(1):99108.

198. Perez EA, Reinholz MM, Hillman DW, Tenner KS, Schroeder MJ, Davidson NE, Martino S, Sledge GW, Harris LN, Gralow JR, Dueck AC, Ketterling RP, Ingle JN, Lingle WL, Kaufman PA, Visscher DW, and Jenkins RB, HER2 and chromosome 17 effect on patient outcome in the N9831 adjuvant trastuzumab trial. J Clin Oncol 2010; 28(28):4307-4315.

199. Perez EA, Suman VJ, Davidson NE, Gralow JR, Kaufman PA, Visscher DW, Chen B, Ingle JN, Dakhil SR, Zujewski J, Moreno-Aspitia A, 
Pisansky TM, and Jenkins RB, Sequential versus concurrent trastuzumab in adjuvant chemotherapy for breast cancer. J Clin Oncol 2011; 29(34):4491-4497.

200. Powell BL, Moser B, Stock W, Gallagher RE, Willman CL, Stone RM, Rowe JM, Coutre S, Feusner JH, Gregory J, Couban S, Appelbaum FR, Tallman MS, and Larson RA, Arsenic trioxide improves event-free and overall survival for adults with acute promyelocytic leukemia: North American Leukemia Intergroup Study C9710. Blood 2010; 116(19):37513757.

201. Rini BI, Halabi S, Rosenberg JE, Stadler WM, Vaena DA, Ou SS, Archer L, Atkins JN, Picus J, Czaykowski P, Dutcher J, and Small EJ, Bevacizumab plus interferon alfa compared with interferon alfa monotherapy in patients with metastatic renal cell carcinoma: CALGB 90206. J Clin Oncol 2008; 26(33):5422-5428.

202. Schwind S, Edwards CG, Nicolet D, Mrózek K, Maharry KM, Wu Y-Z, Paschka P, Eisfeld A-K, Hoellerbauer P, Becker H, Metzeler KH, Curfman J, Kohlschmidt J, Prior TW, Kolitz JE, Blum W, Pettenati MJ, Cin PD, Carroll AJ, Caligiuri MA, Larson RA, Volinia S, Marcucci G, and Bloomfield CD, inv(16)/t(16;16) acute myeloid leukemia with non-type A CBFB-MYH11 fusions associate with distinct clinical and genetic features and lack KIT mutations. Blood 2013; 121(2):385-391. 
203. Stone RM, Dohner H, Ehninger G, Villeneuve M, Teasdale T, Virkus JD, Bressler LR, Seiler MM, Marcucci G, Larson RA. CALGB 10603 (RATIFY): A randomized phase III study of induction (daunorubicin/cytarabine) and consolidation (high-dose cytarabine) chemotherapy combined with midostaurin or placebo in treatment-naive patients with FLT3 mutated AML [abstract]. J Clin Oncol 2011;29: abstr TPS199.

204. Schwind S, Maharry K, Radmacher MD, Mrozek K, Holland KB, Margeson D, Whitman SP, Hickey C, Becker H, Metzeler KH, Paschka P, Baldus CD, Liu S, Garzon R, Powell BL, Kolitz JE, Carroll AJ, Caligiuri MA, Larson RA, Marcucci G, and Bloomfield CD. Prognostic significance of expression of a single microRNA, miR-181a, in cytogenetically normal acute myeloid leukemia: a Cancer and Leukemia Group B study. J Clin Oncol (Meeting Abstracts) 2010; 28(36):52575264.

205. Schwind S, Marcucci G, Kohlschmidt J, Radmacher MD, Mrozek K, Maharry K, Becker H, Metzeler KH, Whitman SP, Wu YZ, Powell BL, Baer MR, Kolitz JE, Carroll AJ, Larson RA, Caligiuri MA, and Bloomfield CD, Low expression of MN1 associates with better treatment response in older patients with de novo cytogenetically normal acute myeloid leukemia. Blood 2011; 118(15):4188-4198. 
206. Schwind S, Marcucci G, Maharry K, Radmacher MD, Mrozek K, Holland KB, Margeson D, Becker H, Whitman SP, Wu YZ, Metzeler KH, Powell BL, Kolitz JE, Carter TH, Moore JO, Baer MR, Carroll AJ, Caligiuri MA, Larson RA, and Bloomfield CD, BAALC and ERG expression levels are associated with outcome and distinct gene and microRNA expression profiles in older patients with de novo cytogenetically normal acute myeloid leukemia: a Cancer and Leukemia Group B study. Blood 2010; 116(25):5660-5669.

207. Shulman LN, Cirrincione CT, Berry DA, Becker HP, Perez EA, O'Regan R, Martino S, Atkins JN, Mayer E, Schneider CJ, Kimmick G, Norton L, Muss H, Winer EP, and Hudis C, Six cycles of Doxorubicin and cyclophosphamide or Paclitaxel are not superior to four cycles as adjuvant chemotherapy for breast cancer in women with zero to three positive axillary nodes: cancer and leukemia group B 40101. J Clin Oncol 2012; 30(33):4071-4076.

208. Sinicrope FA, Rego RL, Okumura K, Foster NR, O'Connell MJ, Sargent DJ, and Windschitl HE, Prognostic impact of bim, puma, and noxa expression in human colon carcinomas. Clin Cancer Res 2008; 14(18):5810-5818.

209. Smith MR, Halabi S, Ryan CJ, Hussain A, Vogelzang N, Stadler W, Hauke RJ, Monk JP, Saylor P, Bhoopalam N, Saad F, Sanford B, Kelly 
WK, Morris M, and Small EJ, Randomized Controlled Trial of Early Zoledronic Acid in Men With Castration-Sensitive Prostate Cancer and Bone Metastases: Results of CALGB 90202 (Alliance). J Clin Oncol 2014; 32(11):1143-1150.

210. Uhm JH, Ballman KV, Wu W, Giannini C, Krauss JC, Buckner JC, James CD, Scheithauer BW, Behrens RJ, Flynn PJ, Schaefer PL, Dakhill SR, and Jaeckle KA, Phase II evaluation of gefitinib in patients with newly diagnosed Grade 4 astrocytoma: Mayo/North Central Cancer Treatment Group Study N0074. Int J Radiat Oncol Biol Phys 2011; 80(2):347-353.

211. Whitman SP, Ruppert AS, Radmacher MD, Mrozek K, Paschka P, Langer C, Baldus CD, Wen J, Racke F, Powell BL, Kolitz JE, Larson RA, Caligiuri MA, Marcucci G, and Bloomfield CD, FLT3 D835/I836 mutations are associated with poor disease-free survival and a distinct gene-expression signature among younger adults with de novo cytogenetically normal acute myeloid leukemia lacking FLT3 internal tandem duplications. Blood 2008; 111(3):1552-1559.

212. Witzig TE, Geyer SM, Kurtin PJ, Colgan JP, Inwards DJ, Micallef IN, Laplant BR, Michalak JC, Salim M, Dalton RJ, Jr DFM, and Reeder CB, Salvage chemotherapy with rituximab DHAP for relapsed non-Hodgkin lymphoma: a phase II trial in the North Central Cancer Treatment Group. Leuk Lymphoma 2008; 49(6):1074-1080. 


\begin{tabular}{|l|l|l|r|r|}
\hline \multicolumn{5}{|c|}{ Table 1. INTERNATIONAL PARTICIPATION IN NCI COOPERATIVE GROUP } \\
CLINICAL TRIALS* \\
$\begin{array}{c}\text { COOP. } \\
\text { GROUP }\end{array}$ & $\begin{array}{l}\text { NUMBER } \\
\text { COUNTRIES }\end{array}$ & $\begin{array}{c}\text { NUMBER } \\
\text { PARTICIPATING } \\
\text { INSTITUTIONS }\end{array}$ & $\begin{array}{c}\text { NUMBER OF } \\
\text { STUDIES }\end{array}$ & $\begin{array}{c}\text { OVERALL } \\
\text { ACCRUAL }\end{array}$ \\
\hline Alliance & 19 & 243 & 402 & 10,105 \\
\hline NCIC-CTG & 41 & 2485 & 54 & 26,189 \\
\hline NSABP & 6 & 41 & 56 & 14,559 \\
\hline RTOG & 9 & 47 & 83 & 4,040 \\
\hline SWOG & 14 & 93 & 48 & 8,925 \\
\hline $\begin{array}{l}\text { *Time periods: Alliance and legacy (1966-present); NCIC-CTG (1980-2014); NSABP } \\
\text { (1971-2014); RTOG (2005-2014); SWOG (1970-present) }\end{array}$ & \multicolumn{5}{|c|}{} \\
\hline
\end{tabular}




\begin{tabular}{|c|c|c|c|c|}
\hline $\begin{array}{l}\text { CONTINENT/ } \\
\text { SUBCONTINENT* }\end{array}$ & $\begin{array}{c}\text { NUMBER } \\
\text { COUNTRIES/ } \\
\text { SITES }\end{array}$ & STUDIES & $\begin{array}{l}\text { OVERALL } \\
\text { ACCRUAL }\end{array}$ & $\begin{array}{l}\text { PUBLICATIONS } \\
\text { (refs) }{ }^{* *}\end{array}$ \\
\hline Africa & $1 / 8$ & BR2, BR21, MA19, OV12 & 97 & \multirow[t]{6}{*}{$(5-49)$} \\
\hline America (North) & $1 / 1696$ & $\begin{array}{l}\text { BR10, BR18, BR19, BR2, BR21, } \\
\text { BR26, BR8, CO10, CO21, CX3, } \\
\text { EN5, HD6, I125, I152, I165, I202, } \\
\text { I48, LY12, MA14, MA17, MA17R, } \\
\text { MA20, MA21, MA27, MA31, } \\
\text { MA32, MAP1, MAP2, MAP3, } \\
\text { MY10, MY7, OV21, PA1, PA3, } \\
\text { PR11, PR3, PR7, SC11, SC20 }\end{array}$ & 18,624 & \\
\hline $\begin{array}{l}\text { America (Central } \\
\text { \& South) }\end{array}$ & $5 / 39$ & $\begin{array}{l}\text { BR21, BR24, BR26, BR29, MA31, } \\
\text { PA3 }\end{array}$ & 419 & \\
\hline Asia & $8 / 60$ & $\begin{array}{l}\text { BR21, BR24, BR26, MA31, CE6, } \\
\text { CO23, , CX5, PA3 }\end{array}$ & 484 & \\
\hline Australia & $2 / 163$ & $\begin{array}{l}\text { BR21, BR24, BR26, BR29, CE6, } \\
\text { CO17, CO20, CO21, CO23, EN5, } \\
\text { HD4, I7, LY12, MA19, MA20, } \\
\text { MA31, PA3, SC20 }\end{array}$ & 1,587 & \\
\hline Europe & $22 / 506$ & $\begin{array}{l}\text { BR12, BR18, BR21, BR24,BR26, } \\
\text { CE6, CX5, HD6, I106, I106B, } \\
\text { I126, I138, LY12, MA17, MA19, , } \\
\text { MA27, MA31, MA32, MAP3, } \\
\text { OV9, OV12, OV16, OV21, PA3, } \\
\text { PR7, PR11, SC20 }\end{array}$ & 4,870 & \\
\hline \multirow[t]{2}{*}{ Middle East } & $2 / 13$ & BR21, CX2,MA31, OV12,PA3 & 108 & \\
\hline & $41 / 2485$ & 54 & 26,189 & \\
\hline \multicolumn{5}{|c|}{$\begin{array}{l}\text { *North America: U.S.; Central \& South American: Argentina, Brazil, Chile, Mexico, Peru; Asia: Hong Kong, India; } \\
\text { Japan, Philippines, Singapore, S. Korea, Taiwan, Thailand); Europe: Austria, Belgium, Croatia, Denmark, Finland, } \\
\text { France, Germany, Greece, Hungary, Italy, Netherlands, Norway, Poland, Portugal, Romania, Russia, Slovakia, Spain } \\
\text { Sweden, Switzerland, Ukraine, United Kingdom; Middle East: Israel and Saudi Arabia } \\
\text { **Source: NCIC CTG }\end{array}$} \\
\hline
\end{tabular}


Table 3. INTERNATIONAL PARTICIPATION IN NCI COOPERATIVE GROUP CLINICAL TRIALS:

NSABP (1971-present)

\begin{tabular}{|c|c|c|c|c|}
\hline \\
\hline COUNTRY & $\begin{array}{l}\text { NUMBER } \\
\text { SITES }\end{array}$ & STUDIES & $\begin{array}{l}\text { OVERALL } \\
\text { ACCRUAL }\end{array}$ & $\begin{array}{l}\text { PUBLICATIONS } \\
\text { (refs)* }\end{array}$ \\
\hline $\begin{array}{l}\text { Australia/ } \\
\text { New } \\
\text { Zealand }\end{array}$ & 2 & B-06, C-06, C-07 & 179 & $(50-103)$ \\
\hline Canada & 36 & $\begin{array}{l}\text { B-04, B-05, B-06, B-07, B-08, B-09, B-10, B-11, } \\
\text { B-12, B-13, B-14, B-15, B-16, B-17, B-18, B-19, } \\
\text { B-20, B-21, B-22, B-23, B-24, B-25, B-26, B-27, } \\
\text { B-28, B-29, B-30, B-31, B-32, B-34, B-35, B-36, } \\
\text { B-37, B-38, B-39, B-40, B-42, B-43, B-47, B-51, } \\
\text { B-52, B-59, C-01, C-02, C-03, C-04, C-05, C-06, } \\
\text { C-07, R-01, R-02, R-03, R-04, P-1, P-2 }\end{array}$ & 13,949 & \\
\hline France & 1 & B-07, B-10 & 47 & \\
\hline Ireland & 1 & C-08, B-38, B-39, B-42, -B47 & 368 & \\
\hline Korea & 1 & B-43 & 16 & \\
\hline 6 & 41 & 56 & 14,559 & \\
\hline
\end{tabular}




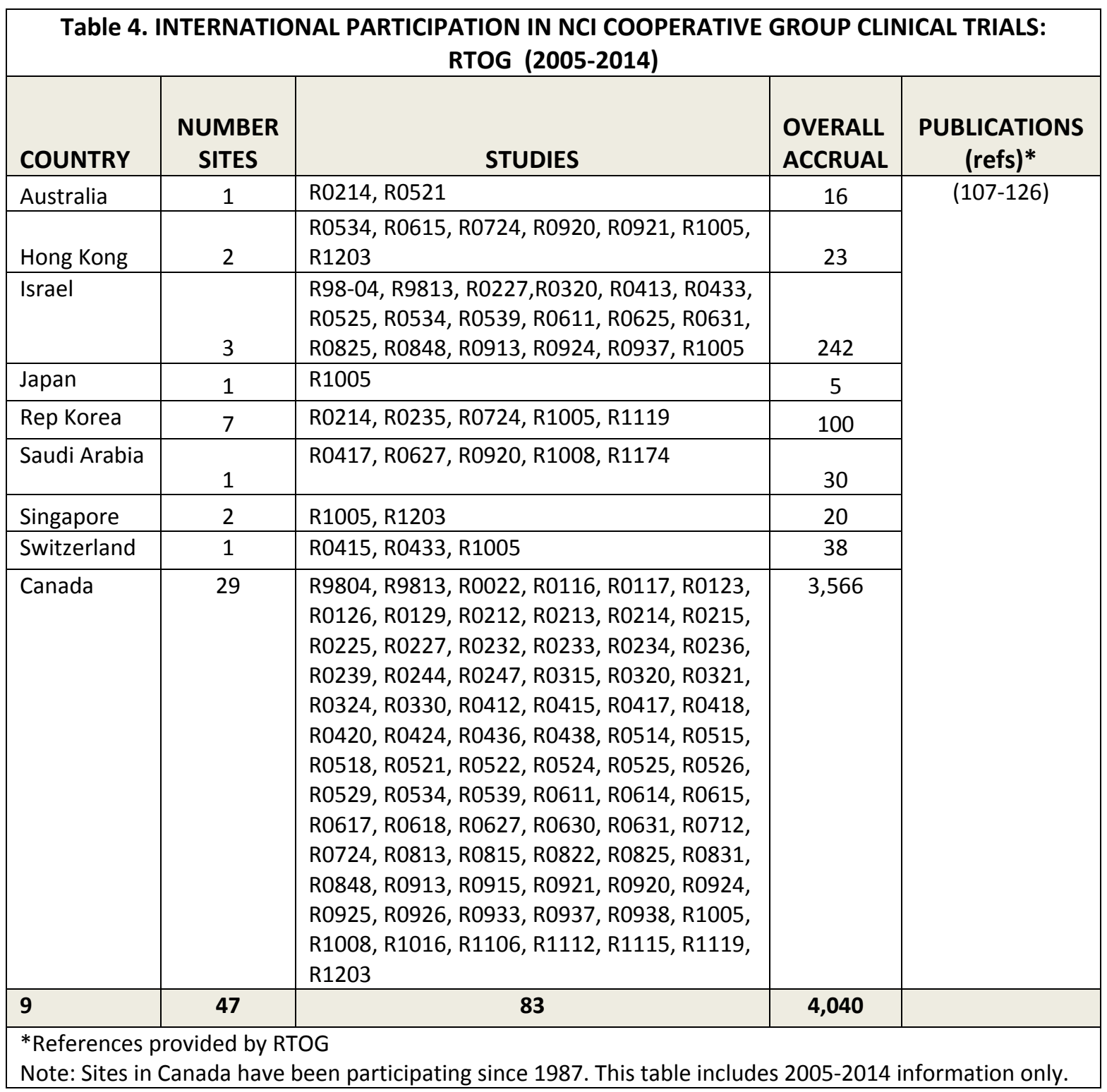




\begin{tabular}{|c|c|c|c|c|}
\hline COUNTRY & $\begin{array}{l}\text { NUMBER } \\
\text { SITES }\end{array}$ & STUDIES & $\begin{array}{l}\text { OVERALL } \\
\text { ACCRUAL }\end{array}$ & $\begin{array}{l}\text { PUBLICATIONS } \\
\text { (refs)* }\end{array}$ \\
\hline Canada & 66 & $\begin{array}{l}\text { S0000, S0033, S0106, S0205, S0772/S0773, } \\
\text { s0774/ S0775, S0221, S0226,S1117, S1203, } \\
\text { S7204, S7827, S7936, S8110, S8710, S9013, } \\
\text { s9114, S9304, S9321, S9346, S9436, S9462, } \\
\text { s9463, S9704, S9900 }\end{array}$ & 4,522 & $(127-161)$ \\
\hline Chile & 1 & S0701 & 277 & \\
\hline Columbia & 2 & S1007, S0701 & 259 & \\
\hline Costa Rica & 1 & S0701 & 276 & \\
\hline Egypt & 1 & $\begin{array}{l}\text { S7436, S7519, S7521, S7524, S7610, S7613, } \\
\text { S7632, S7727, S7765, S7814, S7817, S7820, } \\
\text { S7965 }\end{array}$ & 268 & \\
\hline Honduras & 1 & S0701 & 259 & \\
\hline Korea & 2 & S1007, S9008 & 98 & \\
\hline Mexico & 4 & S1007, S0819, S0702, S0701, S7315 & 678 & \\
\hline Nicaragua & 1 & S0701 & 241 & \\
\hline Peru & 2 & S7416, S7426 & 40 & \\
\hline Puerto Rico & 9 & S0774/S0775, S0000 & 1,463 & \\
\hline Saudi Arabia & 1 & \begin{tabular}{l|l} 
S0230, S0777, S0702 \\
\end{tabular} & 32 & \\
\hline Spain & 1 & S1007 & 499 & \\
\hline Sweden & 1 & S0106 & 13 & \\
\hline 14 & 93 & 48 & 8,925 & \\
\hline
\end{tabular}




\begin{tabular}{|c|c|c|c|c|}
\hline \multicolumn{5}{|c|}{$\begin{array}{l}\text { Table 6. INTERNATIONAL PARTICIPATION IN NCI COOPERATIVE GROUP CLINICAL TRIALS: } \\
\text { Alliance for Clinical Trials in Oncology and Legacy Groups (1966-present)* }\end{array}$} \\
\hline COUNTRIES & $\begin{array}{l}\text { NUMBER } \\
\text { SITES }\end{array}$ & STUDIES & $\begin{array}{l}\text { OVERALL } \\
\text { ACCRUAL }\end{array}$ & $\begin{array}{l}\text { PUBLICATIONS } \\
\text { (refs) } t\end{array}$ \\
\hline Australia & 3 & $\begin{array}{l}\text { CALGB-10603, CALGB-140503, CALGB-580602, Z0010, } \\
\text { Z0011, Z0030 }\end{array}$ & 103 & \multirow[t]{18}{*}{$(162-212)$} \\
\hline Austria & 1 & N0577 & 1 & \\
\hline Belgium & 1 & N0577 & 2 & \\
\hline Canada & 76 & $\begin{array}{l}\text { ACOSOG = } 17 \text { studies from } 1990 \text { to present } \\
\text { CALGB = } 215 \text { studies from } 1966 \text { to present } \\
\text { NCCTG = } 147 \text { studies from } 1979 \text { to present } \\
\text { Alliance = } 1 \text { study (A021202) from } 2013 \text { to present }\end{array}$ & 7,513 & \\
\hline Denmark & 1 & CALGB = 60 studies from 1966 to 1992 & 771 & \\
\hline France & 4 & N0147, N0577 & 6 & \\
\hline Germany & 73 & CALGB-10603 & 328 & \\
\hline $\begin{array}{l}\text { Great Britain } \\
\text { (UK) }\end{array}$ & 20 & C9581, N0147 & 96 & \\
\hline Hungary & 1 & CALGB-10603 & 2 & \\
\hline Ireland & 3 & Z1031, Z0010, Z0011, Z1031 & 117 & \\
\hline Israel & 1 & C9710 & 15 & \\
\hline Italy & 24 & CALGB-10603 & 105 & \\
\hline Mexico & 1 & N0021, N0032, N0424, N0691 & 23 & \\
\hline Netherlands & 18 & C9581, N0577 & 51 & \\
\hline New Zealand & 1 & N9431 & 159 & \\
\hline Peru & 1 & $\begin{array}{l}\text { C150106, C70103, C9710, CALGB-10403, CALGB-49907, } \\
\text { N9831 }\end{array}$ & 94 & \\
\hline South Africa & 2 & CALGB-40101, N0691, N0832, N9741, N9831, N9841 & 94 & \\
\hline Spain & 8 & CALGB-10603 & 22 & \\
\hline Switzerland & 4 & CALGB = 34 studies from 1966 to 1981 & 617 & \\
\hline 19 & 243 & 402 & 10,105 & \\
\hline
\end{tabular}

